Prepared in cooperation with the city of Sioux Falls

\title{
Occurrence of Anthropogenic Organic Compounds and Nutrients in Source and Finished Water in the Sioux Falls Area, South Dakota, 2009-10
}
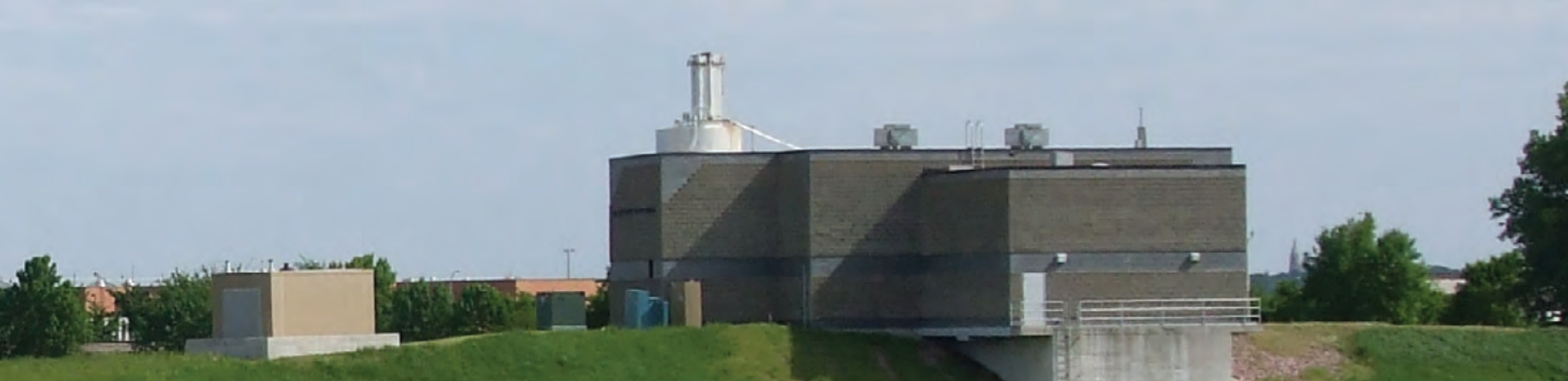

$x^{2}$

Scientific Investigations Report 2012-5098

U.S. Department of the Interior

U.S. Geological Survey 
Cover photograph. Surface-water intake station on the Big Sioux River north of Sioux Falls, South Dakota. 


\section{Occurrence of Anthropogenic Organic Compounds and Nutrients in Source and Finished Water in the Sioux Falls Area, South Dakota, 2009-10}

By Galen K. Hoogestraat

Prepared in cooperation with the city of Sioux Falls

Scientific Investigations Report 2012-5098 


\section{U.S. Department of the Interior \\ KEN SALAZAR, Secretary \\ U.S. Geological Survey \\ Marcia K. McNutt, Director}

U.S. Geological Survey, Reston, Virginia: 2012

For more information on the USGS - the Federal source for science about the Earth, its natural and living resources, natural hazards, and the environment, visit http://www.usgs.gov or call 1-888-ASK-USGS.

For an overview of USGS information products, including maps, imagery, and publications,

visit http://www.usgs.gov/pubprod

To order other USGS information products, visit http://store.usgs.gov

Any use of trade, product, or firm names is for descriptive purposes only and does not imply endorsement by the U.S. Government.

Although this report is in the public domain, permission must be secured from the individual copyright owners to reproduce any copyrighted materials contained within this report.

Suggested citation:

Hoogestraat, G.K., 2012, Occurrence of anthropogenic organic compounds and nutrients in source and finished water in the Sioux Falls area, South Dakota, 2009-10: U.S. Geological Survey Scientific Investigations Report 2012-5098,

21 p. plus appendixes. 


\section{Contents}

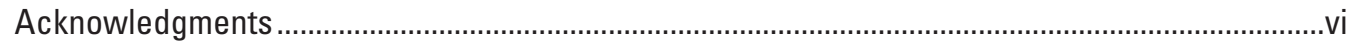

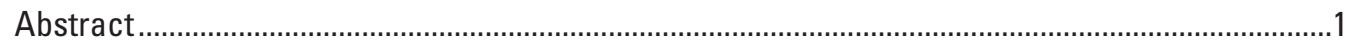

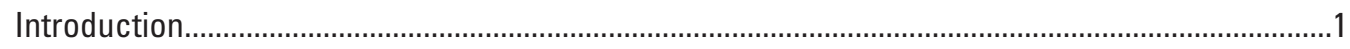

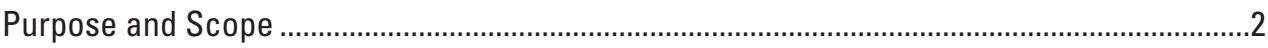

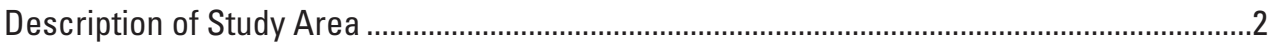

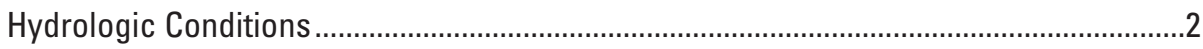

Land Use and Wastewater Discharge ........................................................................... 4

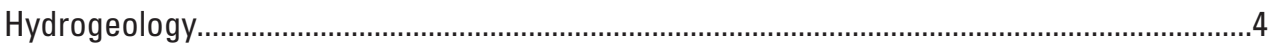

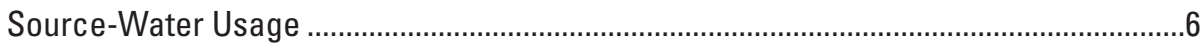

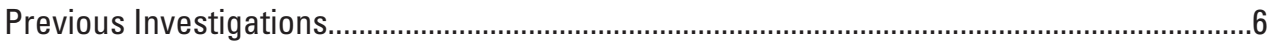

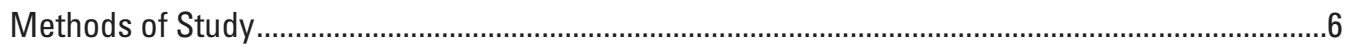

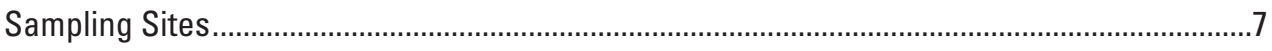

Collection, Processing, and Analysis of Water Samples .......................................................

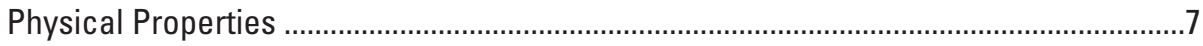

Anthropogenic Organic Compounds ..............................................................................

Nutrients and Nitrogen and Oxygen Isotope Ratios in Nitrate .......................................8

Quality Assurance / Quality Control.............................................................................................

Occurrence of Anthropogenic Organic Compounds and Nutrients.................................................10

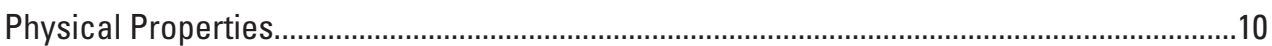

Anthropogenic Organic Compounds ..........................................................................................11

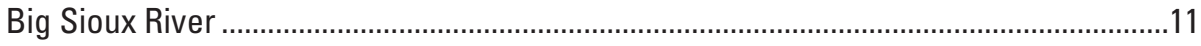

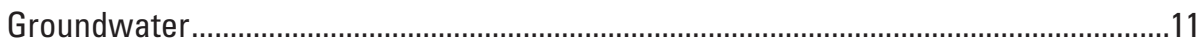

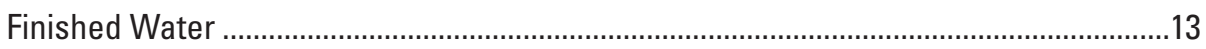

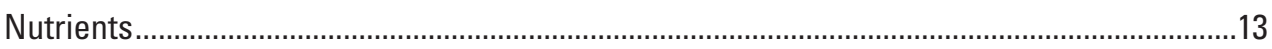

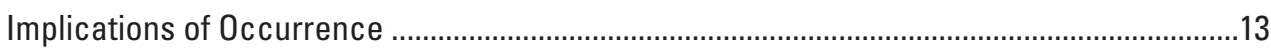

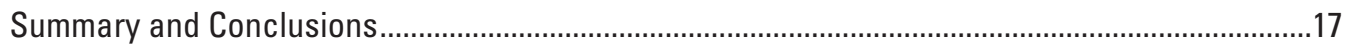

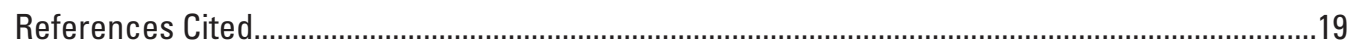

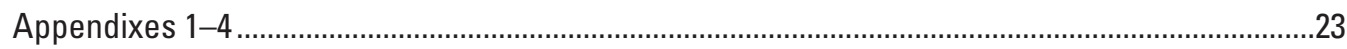




\section{Figures}

1. Map showing location of Big Sioux River Basin and selected data-collection sites in the Sioux Falls area

2. Graph showing streamflow in the Big Sioux River near Dell Rapids and groundwater levels in the Big Sioux aquifer, March 2009 to September 2010

3. Pie chart showing land use in the Big Sioux River Basin .4

4. Map showing surface drainage and approximate extent of aquifers used for water supplies in the Sioux Falls area

5. Graph showing daily mean water temperature and specific conductance at the Big Sioux River near Dell Rapids (streamgage 06481000), March 2009 to September 2010.

6. Graph showing nitrogen isotope ratios in nitrate for source-water samples in relation to the isotopic composition of nitrate sources, 2009-10

7. Graph showing nitrogen and oxygen isotope ratios in nitrate of source-water samples

8. Graphs showing maximum concentrations and benchmark quotient values for detected anthropogenic organic compounds that have a relevant benchmark

9. Graph showing atrazine concentration in source- and finished-water samples, 2009-10

\section{Tables}

1. Precipitation totals and mean annual streamflow in the Big Sioux River in the Sioux Falls area, water years 2001-10

2. Study sampling dates and source-water components used for day sampled.

3. Detection frequency, maximum concentration, and maximum benchmark quotient for anthropogenic organic compounds detected in at least 20 percent of samples at any site.

4. Concentrations of nutrients and nitrogen and oxygen isotope ratios in nitrate in source water

5. Analyte and the corresponding isotope dilution standard (IDS) used for its quantification. 


\section{Conversion Factors}

Inch/Pound to SI

\begin{tabular}{lll}
\hline \multicolumn{1}{c}{ Multiply } & \multicolumn{1}{c}{ By } & \multicolumn{1}{c}{ To obtain } \\
\hline inch (in.) & \multicolumn{2}{c}{ Length } \\
mile (mi) & 2.54 & centimeter $(\mathrm{cm})$ \\
foot $(\mathrm{ft})$ & 1.609 & kilometer $(\mathrm{km})$ \\
\hline \multicolumn{2}{c}{0.3048} & meter $(\mathrm{m})$ \\
\hline square mile $\left(\mathrm{mi}^{2}\right)$ & \multicolumn{2}{c}{ Area } \\
square mile $\left(\mathrm{mi}^{2}\right)$ & 259.0 & hectare $(\mathrm{ha})$ \\
\hline \multicolumn{2}{c}{ Volume } & square kilometer $\left(\mathrm{km}^{2}\right)$ \\
\hline gallon $(\mathrm{gal})$ & 2.590 & liter $(\mathrm{L})$ \\
cubic foot $\left(\mathrm{ft}^{3}\right)$ & 3.785 & cubic meter $\left(\mathrm{m}^{3}\right)$ \\
\hline \multicolumn{2}{c}{ Flow rate } & \\
\hline cubic foot per second $\left(\mathrm{ft}^{3} / \mathrm{s}\right)$ & 0.02832 & cubic meter per second $\left(\mathrm{m}^{3} / \mathrm{s}\right)$ \\
\hline
\end{tabular}

Temperature in degrees Celsius $\left({ }^{\circ} \mathrm{C}\right)$ may be converted to degrees Fahrenheit $\left({ }^{\circ} \mathrm{F}\right)$ as follows:

$$
{ }^{\circ} \mathrm{F}=\left(1.8 x^{\circ} \mathrm{C}\right)+32
$$

Concentrations of chemical constituents in water are given either in milligrams per liter (mg/L) or micrograms per liter $(\mu \mathrm{g} / \mathrm{L})$. Values of stable isotopes of nitrogen and oxygen are given in per mil $(\%)$.

Water year (WY) is the 12-month period, October 1 through September 30, and is designated by the calendar year in which it ends. Thus, the water year ending September 30, 2009, is called the "2009" water year.

\section{Abbreviations and Acronyms}

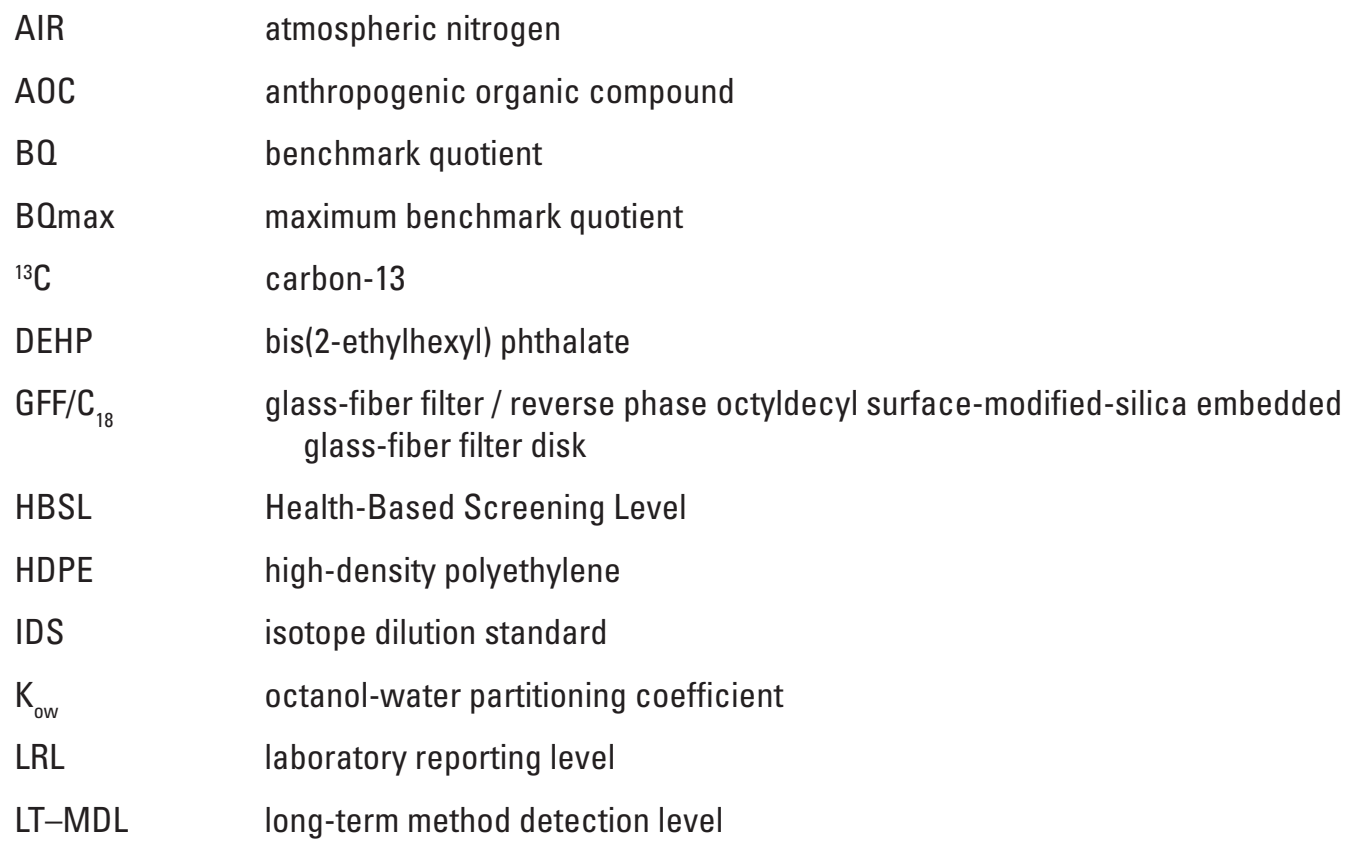




$\begin{array}{ll}\mathrm{MCL} & \text { Maximum Contaminant Level } \\ \mathrm{mg} / \mathrm{L} \text { as } \mathrm{N} & \text { milligrams per liter as nitrogen } \\ \mathrm{mL} & \text { milliliter } \\ \mathrm{MRL} & \text { minimum reporting level } \\ \mathrm{MSTFA} & \mathrm{N} \text {-methyl- } \mathrm{N} \text {-(trimethylsilyl)-trifluoroacetamide } \\ \mathrm{N}_{2} & \text { nitrogen gas } \\ \mathrm{NO}_{2}+\mathrm{NO}_{3} & \text { nitrite plus nitrate } \\ \mathrm{NWQL} & \text { National Water Quality Laboratory } \\ \text { OGRL } & \text { Organic Geochemistry Research Laboratory } \\ \mathrm{RSIL} & \text { Reston Stable Isotope Laboratory } \\ \mathrm{SPE} & \text { solid-phase extraction } \\ \text { USEPA } & \text { U.S. Environmental Protection Agency } \\ \text { USGS } & \text { U.S. Geological Survey } \\ \text { VSMOW } & \text { Vienna Standard Mean Ocean Water } \\ \delta^{15} \mathrm{~N} & \text { isotope ratio of }{ }^{15} \mathrm{~N} \text { to }{ }^{14} \mathrm{~N} \text { relative to atmospheric nitrogen } \\ \delta^{18} \mathrm{O} & \text { isotope ratio of }{ }^{18} \mathrm{O} \text { to }{ }^{16} \mathrm{O} \text { relative to Vienna Standard Mean Ocean Water }\end{array}$

\section{Acknowledgments}

The author would like to recognize the contributions made to this study by Tim Stefanich from the city of Sioux Falls in providing valuable background information and access to sampling locations.

Special thanks to William Foreman, James Gray, and Rhiannon ReVello from the U.S. Geological Survey National Water Quality Laboratory for their efforts in developing the analytical method used for the analysis of hormones. Appreciation is given to Michael Meyer and Julie Dietze from the U.S. Geological Survey Kansas Organic Geochemistry Research Laboratory for their assistance in providing laboratory analyses of antibiotics. 


\title{
Occurrence of Anthropogenic Organic Compounds and Nutrients in Source and Finished Water in the Sioux Falls Area, South Dakota, 2009-10
}

\author{
By Galen K. Hoogestraat
}

\section{Abstract}

Anthropogenic organic compounds (AOCs) in drinkingwater sources commonly are derived from municipal, agricultural, and industrial wastewater sources, and are a concern for water-supply managers. A cooperative study between the city of Sioux Falls, S. Dak., and the U.S. Geological Survey was initiated in 2009 to (1) characterize the occurrence of anthropogenic organic compounds in the source waters (groundwater and surface water) to water supplies in the Sioux Falls area,

(2) determine if the compounds detected in the source waters also are present in the finished water, and (3) identify probable sources of nitrate in the Big Sioux River Basin and determine if sources change seasonally or under different hydrologic conditions. This report presents analytical results of waterquality samples collected from source waters and finished waters in the Sioux Falls area.

The study approach included the collection of water samples from source and finished waters in the Sioux Falls area for the analyses of AOCs, nutrients, and nitrogen and oxygen isotopes in nitrate. Water-quality constituents monitored in this study were chosen to represent a variety of the contaminants known or suspected to occur within the Big Sioux River Basin, including pesticides, pharmaceuticals, sterols, household and industrial products, polycyclic aromatic hydrocarbons, antibiotics, and hormones. A total of $184 \mathrm{AOCs}$ were monitored, of which 40 AOCs had relevant human-health benchmarks.

During 11 sampling visits, 45 AOCs (24 percent) were detected in at least one sample of source or finished water, and 13 AOCs were detected in at least 20 percent of all samples. Concentrations of detected AOCs were all less than 1 microgram per liter, except for two AOCs in multiple samples from the Big Sioux River, and one AOC in finished-water samples. Concentrations of AOCs were less than 0.1 microgram per liter in more than 75 percent of the detections. Nutrient concentrations varied seasonally in source-water samples from surface water and groundwater. In the Big Sioux River, nitrite plus nitrate concentrations were typically less than 1 milligram per liter as nitrogen, and reached a maximum of 4.06 milligrams per liter as nitrogen following a June 2010 storm. Nitrite plus nitrate concentrations in groundwater ranged from less than 0.1 to 0.701 milligram per liter as nitrogen.

Eight of the AOCs detected have a human-health benchmark that could be used to evaluate the concentrations in a human-health context. Four AOCs had maximum concentrations within an order of magnitude of the benchmark, indicating that additional monitoring of the compound may be warranted. Three herbicides (atrazine, metolachlor, and prometon) and one degradate (deethylatrazine) were detected in finished-water samples as frequently as in source-water samples. The concentrations of herbicides in source water varied by an order of magnitude from the period of peak use (early summer) to the winter months. Groundwater and finished-water concentrations of atrazine were similar for the six sampling dates when groundwater was the only source water used. Upstream wastewater discharges contributed a fairly small percentage of the flow to the Big Sioux River near Sioux Falls, but several AOCs associated with wastewater were frequently detected. The interpretation of all potential sources of nitrogen cannot be accomplished by use of nitrogen and oxygen isotopes in nitrate alone, but provides a qualitative indication that very little nitrate originates from excess fertilizer runoff, and most nitrate originates from municipal wastewater effluent, manure runoff (either from field application or feeding operations), or fertilizers mineralized by processes in the soil.

\section{Introduction}

Anthropogenic organic compounds (AOCs) in drinkingwater sources commonly are derived from municipal, agricultural, and industrial wastewater sources, and are a concern for water-supply managers. Recent studies have documented the occurrence of AOCs at very low concentrations in sourcewater supplies and in finished water (Kingsbury and others, 2008; Focazio and others, 2008). Source water is defined as the raw water supply prior to treatment, and finished water is defined as water that has been through the treatment 
process just prior to distribution. Although some of the most commonly used and toxic AOCs are regulated, most are unregulated, and human-health effects from many AOCs are uncertain. A better understanding of the occurrence of AOCs in drinking-water sources is important for water-treatment planning and for characterizing how activities on the landscape affect the quality of drinking-water sources.

During 2000-08, the city of Sioux Falls, S. Dak., observed an increase in nitrate concentrations in source-water samples from the Big Sioux River (Tim Stefanich, city of Sioux Falls, written comm., 2009), prompting questions about the causes of this increase. Water managers identified a need to investigate potential contaminant origins when peaks in nitrate concentrations occur in source water. AOCs may provide insight on the type of sources that lead to peak concentrations of regulated contaminants such as nitrate in public-water supplies. A cooperative study between the city of Sioux Falls and the U.S. Geological Survey (USGS) was initiated in 2009 to (1) characterize the occurrence of AOCs in source waters (groundwater and surface water) to water supplies in the Sioux Falls area, (2) determine if the compounds found in the source waters also are present in the finished water, and (3) identify probable sources of nitrate in the Big Sioux River Basin and determine if sources change seasonally or under different hydrologic conditions.

\section{Purpose and Scope}

This report presents analytical results of water-quality samples collected from source waters (groundwater and surface water) and finished water in the Sioux Falls area. Samples for analysis of AOCs and nutrients were collected on 11 days spaced monthly or bi-monthly between June 2009 and August 2010. On each sampling date, source-water samples were collected from one groundwater site, one surface-water site, or both sites depending on the source(s) to water supplies at the time of sampling; finished-water samples were collected from one site. Characterization of analytical results includes comparison of source-water occurrence to finished-water occurrence on the same day, temporal trends at each site during 2009-10, comparison of the detected concentrations to relevant benchmark standards, and evaluation of potential sources of water-quality constituents during different seasons or hydrologic conditions. This report is not intended to assess the efficacy of the water-treatment plant process for removal of organic compounds.

\section{Description of Study Area}

The Big Sioux River Basin (fig. 1) includes a contributing drainage area of about 3,130 square miles $\left(\mathrm{mi}^{2}\right)$ upstream from Sioux Falls. The annual mean streamflow for the USGS streamgage 06481000 (Big Sioux River near Dell Rapids, S. Dak., contributing drainage area $=3,057 \mathrm{mi}^{2}$ ) for water years 1972-2008 was 529 cubic feet per second $\left(\mathrm{ft}^{3} / \mathrm{s}\right)$
(U.S. Geological Survey, 2011). The annual mean streamflow downstream at the USGS streamgage 06482020 (Big Sioux River at North Cliff Avenue at Sioux Falls, S. Dak., contributing drainage area $=3,778 \mathrm{mi}^{2}$ ) for water years $1972-2008$ was $672 \mathrm{ft}^{3} / \mathrm{s}$, which includes contribution from the $606-\mathrm{mi}^{2}$ Skunk Creek Basin and most of the urbanized area within Sioux Falls (U.S. Geological Survey, 2011). A diversion dam for flood control on the Big Sioux River near the northern edge of Sioux Falls allows the flow of the Big Sioux River to be partially routed through the diversion channel (fig. 1).

\section{Hydrologic Conditions}

The 2009-10 water-quality sampling period represented two extremes in terms of the prevailing hydrologic conditions. Water year 2009 (October 1, 2008, to September 30, 2009) was the driest year of the decade (table 1) for the Sioux Falls area, whereas water year 2010 had the most precipitation (43.1 inches (in.)) in the 120-year period of record (National Oceanic and Atmospheric Administration, 2000-10). In 2010, mean annual streamflow at USGS streamgage 06482020 $\left(1,938 \mathrm{ft}^{3} / \mathrm{s}\right)$ was almost four times greater than the previous year $\left(509 \mathrm{ft}^{3} / \mathrm{s}\right)$ (U.S. Geological Survey, 2011).

Maximum streamflow in the Big Sioux River Basin typically occurs in early spring as a result of snowmelt, when flooding conditions are frequent. Streamflow gradually decreases from summer until the following spring. Nearly two-thirds of the average yearly precipitation falls during the growing season of April through August, and thunderstorms are frequent during the late spring and summer with

Table 1. Precipitation totals and mean annual streamflow in the Big Sioux River in the Sioux Falls area, water years 2001-10.

[USGS, U.S. Geological Survey; $\mathrm{ft}^{3} / \mathrm{s}$, cubic feet per second]

\begin{tabular}{|c|c|c|c|}
\hline $\begin{array}{l}\text { Water } \\
\text { year }\end{array}$ & $\begin{array}{c}\text { Total } \\
\text { precipitation' } \\
\text { (inches) }\end{array}$ & $\begin{array}{c}\text { Mean annual } \\
\text { streamflow }{ }^{2} \text { at } \\
\text { USGS streamgage } \\
06482020 \\
\left(\mathrm{ft}^{\mathrm{t}} / \mathrm{s}\right)\end{array}$ & $\begin{array}{c}\text { Mean annual } \\
\text { streamflow }{ }^{2} \text { at } \\
\text { USGS streamgage } \\
06481000 \\
\left(\mathrm{ft}^{3} / \mathrm{s}\right)\end{array}$ \\
\hline 2001 & 27.6 & 1,309 & 1,068 \\
\hline 2002 & 26.6 & 348 & 306 \\
\hline 2003 & 23.2 & 162 & 110 \\
\hline 2004 & 34.4 & 244 & 156 \\
\hline 2005 & 27.9 & 344 & 269 \\
\hline 2006 & 29.1 & 679 & 485 \\
\hline 2007 & 27.3 & 819 & 613 \\
\hline 2008 & 25.6 & 605 & 464 \\
\hline 2009 & 22.5 & 509 & 437 \\
\hline 2010 & 43.1 & 1,938 & 1,535 \\
\hline
\end{tabular}

${ }^{1}$ At National Weather Service station identified by international call sign KFSD (fig. 1). Data from National Oceanic and Atmospheric Administration (2000-10).

${ }^{2}$ Data from U.S. Geological Survey (2011). 

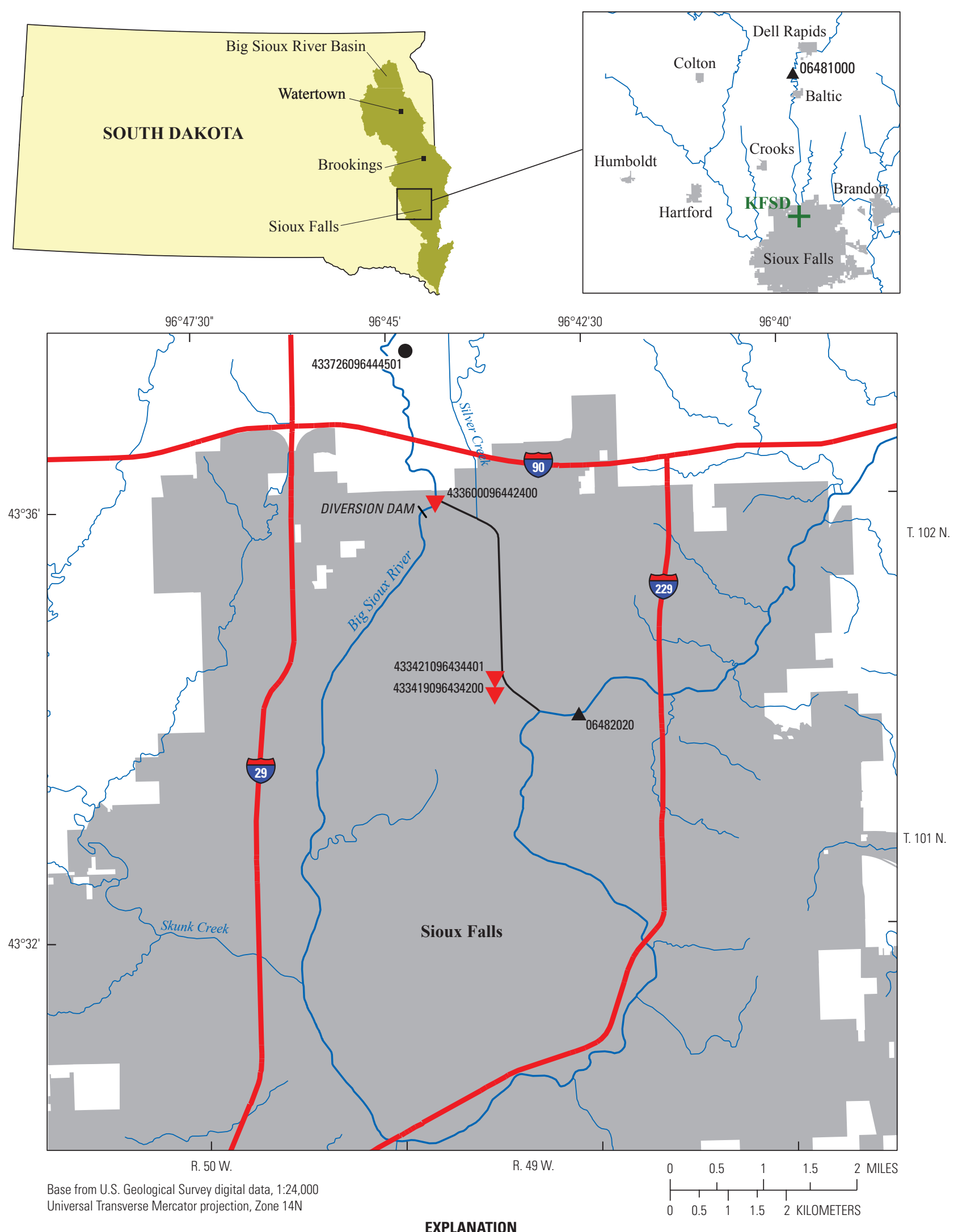

Universal Transverse Mercator projection, Zone 14N

EXPLANATION

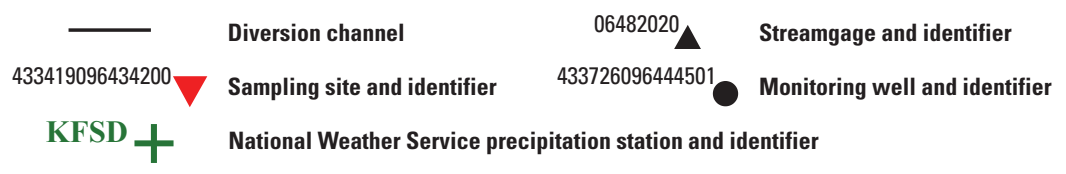

Figure 1. Location of Big Sioux River Basin and selected data-collection sites in the Sioux Falls area. 
June and July the most active months (National Oceanic and Atmospheric Administration, 2000-10). October 2009 was an unusually wet month, with more than 5.5 in. of precipitation that caused a sustained increase in fall streamflow in the Big Sioux River (fig. 2). From June to August 2010, frequent intense thunderstorms maintained streamflow at more than $1,000 \mathrm{ft}^{3} / \mathrm{s}$, typical of spring snowmelt conditions but uncommon for mid-summer streamflow in the Big Sioux River near Sioux Falls. June 2010 had 4 days with more than an inch of precipitation (total of 7.8 in. for June), July had two separate storms that produced more than 2 in. each day (total of 8.6 in. for July), and August had two separate storms with more than 1.5 in. of precipitation (total of 6.3 in. for August). Changes in groundwater levels in the Big Sioux aquifer at USGS monitoring well 433726096444501 correspond to changes in streamflow in the Big Sioux River (fig. 2; U.S. Geological Survey, 2011).

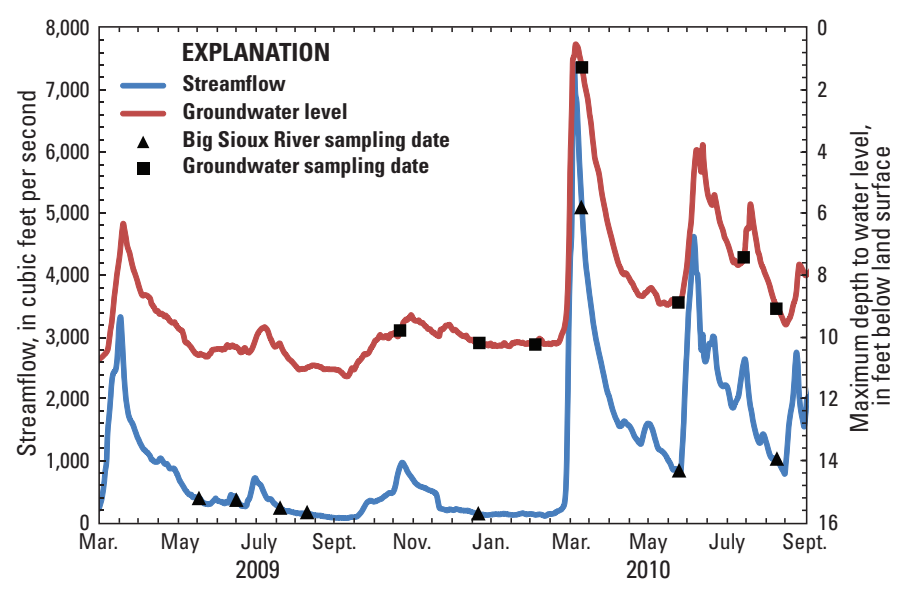

Figure 2. Streamflow in the Big Sioux River near Dell Rapids (streamgage 06481000) and groundwater levels in the Big Sioux aquifer (monitoring well 433726096444501), March 2009 to September 2010.

\section{Land Use and Wastewater Discharge}

Agricultural activities are extensive throughout the Big Sioux River Basin, and the largest cities in the basin have developed along the Big Sioux River, contributing urban runoff and wastewater effluent discharges. About 60 percent of the drainage basin is used for cultivated crops (fig. 3), and other agricultural activities in the basin include livestock and concentrated animal-feeding operations (Homer and others, 2004). Crops grown in the basin include predominantly corn, soybeans, wheat, and alfalfa; livestock raised in the basin primarily include dairy cattle, beef cattle, and hogs (Lawrence and Sando, 1991).

Sioux Falls is the largest city in South Dakota, and its population increased from 124,000 in 2000 to 154,000 in 2010 (U.S. Census Bureau, 2011). Brookings and Watertown (the 4th and 5th largest cities in the State, respectively) are upstream in the basin and discharge treated wastewater

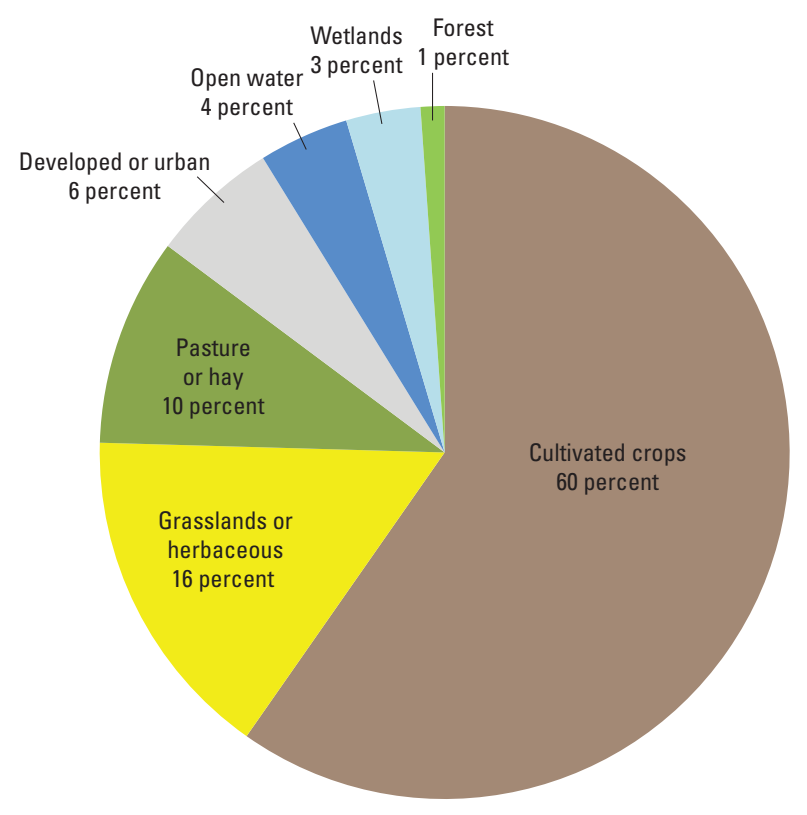

Figure 3. Land use in the Big Sioux River Basin (data from Homer and others, 2004).

effluent to the Big Sioux River. During low-flow periods, the wastewater discharges for Watertown can account for more than 75 percent of the Big Sioux River streamflow for several miles downstream, and the wastewater discharges for Brookings can account for more than 25 percent of the Big Sioux River streamflow for several miles downstream (Sando and others, 2005). Other communities between Watertown and Sioux Falls contribute smaller intermittent wastewater discharges to the Big Sioux River from lagoons or holding ponds. During this study (2009-10), total wastewater discharges accounted for less than 23 percent of the flow in the Big Sioux River near Watertown, less than 15 percent of the flow near Brookings, and less than 10 percent of the flow near Dell Rapids (Mike Boerger, city of Watertown, written comm., 2011; Eric Witt, Brookings Municipal Utilities, written comm., 2011; U.S. Environmental Protection Agency, 2011c; U.S. Geological Survey, 2011). For the summer months (JuneAugust), upstream wastewater discharges averaged 3.5 percent of the flow near Dell Rapids in 2009 and 0.8 percent of the flow in 2010.

\section{Hydrogeology}

Major aquifers in the Sioux Falls area (fig. 4) are described in this section of the report. Additional aquifers in the Sioux Falls area are described in Lindgren and Niehus (1992). Glacial outwash deposits along the Big Sioux River and its tributaries underlie much of the Big Sioux River Basin and are the major source of groundwater in the basin (Lawrence and Sando, 1991). Outwash deposits include the various units that contain the Big Sioux aquifer, which is one of the more extensively developed glacial aquifers in 


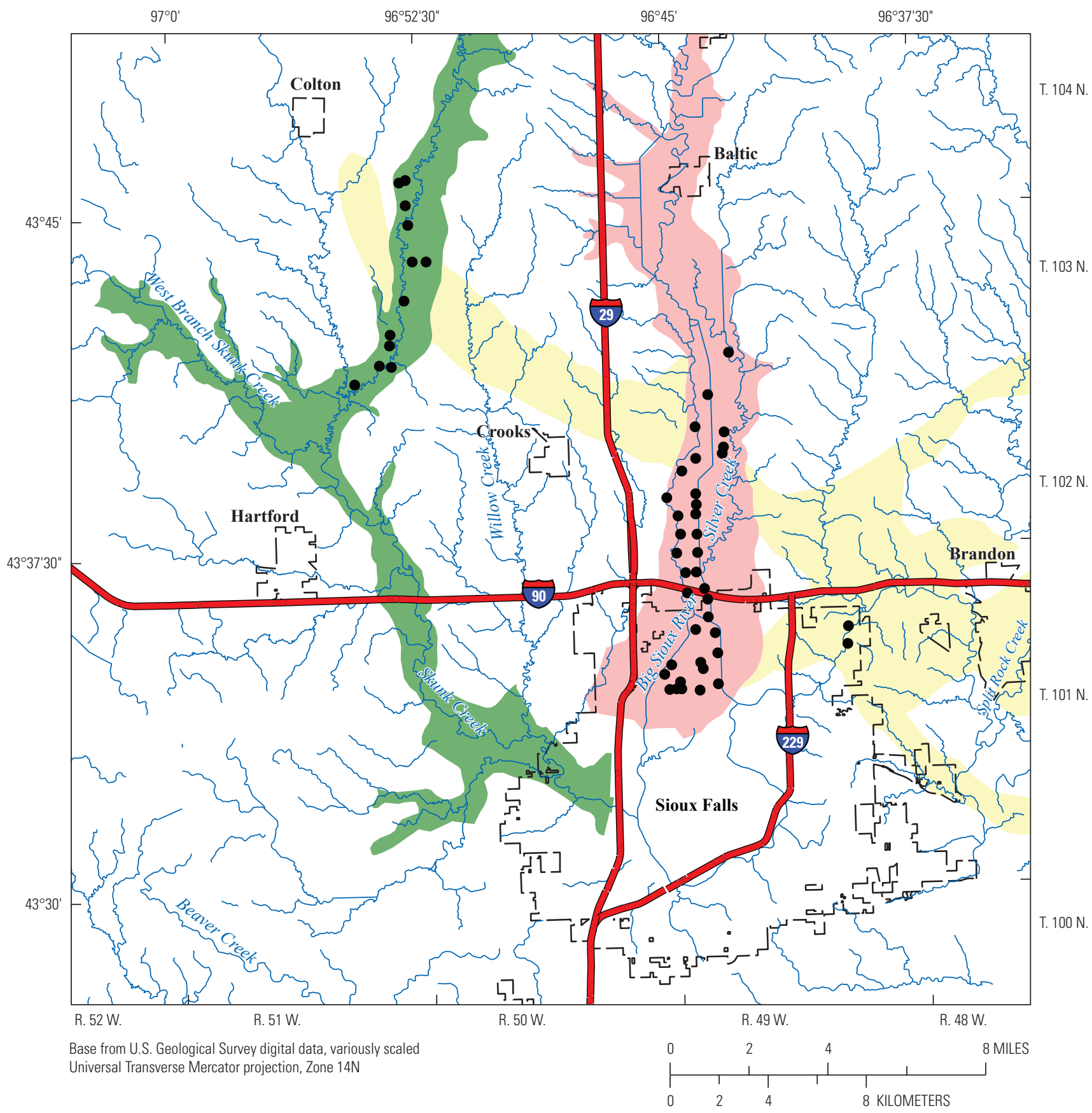

EXPLANATION

Big Sioux aquifer-Modified from Martin and others, 2004

Skunk Creek aquifer-Modified from Martin and others, 2004

Split Rock Creek aquifer-Modified from Martin and others, 2004

- Production well

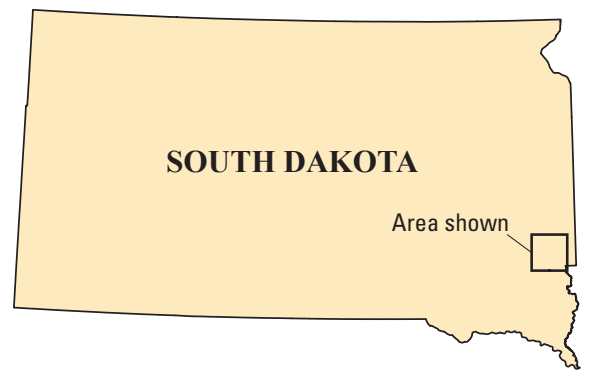

Figure 4. Surface drainage and approximate extent of aquifers used for water supplies in the Sioux Falls area. 
South Dakota, the Skunk Creek aquifer, and several other glacial aquifers. The outwash deposits consist of cross-bedded gravel, sand, and silt that range in thickness from a few feet to about 200 feet (ft) and range in depth below land surface from about 1 to $100 \mathrm{ft}$ (Lawrence and Sando, 1991). Many of the outwash deposits have areas where they are hydraulically connected to the Big Sioux River and can be sensitive to infiltration of surface contaminants (Sando and others, 2006).

The Split Rock Creek aquifer is a major bedrock aquifer in the Sioux Falls area. The Split Rock Creek aquifer is composed of layers of predominantly quartz sand interbedded with layers of siltstone, shale, and silty clay of the Late Cretaceous-age Split Rock Creek Formation (Lindgren and Niehus, 1992).

\section{Source-Water Usage}

Sources of groundwater used for water supplies in the Sioux Falls area include collection galleries or production wells completed in the shallow glacial or bedrock aquifers to the north and northwest of Sioux Falls (fig. 4). The city of Sioux Falls currently (2011) uses groundwater as its primary water source year-round (City of Sioux Falls, 2011) and supplements the supply with surface water from the Big Sioux River only during periods of increased demand (typically in the summer months). For days when the source water was blended in 2009-10, groundwater typically made up about two-thirds of the supply with water from the Big Sioux River making up the difference. Water from the Big Sioux aquifer accounted for nearly 90 percent of the groundwater pumped for public supply in 2009-10 and about 80 percent of the total water supply in the same period. Water from the Skunk Creek aquifer (fig. 4) made up about 10 percent of the groundwater supply in 2009-10, and water from the Split Rock Creek aquifer accounted for less than 1 percent of the groundwater supply in the same period. The Big Sioux River accounted for about 18 percent of the total water supply in 2009 but made up less than 3 percent of the total in 2010 because of a decreased demand during a very wet year (table 1). Usage of the surfacewater source was higher in earlier years, such as 2008 when nearly 37 percent of the water supply came from the Big Sioux River.

\section{Previous Investigations}

Sando and others (2006) characterized the occurrence of compounds commonly associated with wastewater effluent in the finished water, wastewater effluent, and the Big Sioux River near Sioux Falls. During that study, only one AOC (the herbicide metolachlor) was detected in finished water at a concentration greater than laboratory reporting levels. Several other AOCs (primarily agricultural herbicides, pharmaceuticals, and wastewater compounds) were detected in samples from the Big Sioux River (USGS site 433600096442400 , fig. 1). Sando and others (2005) documented the occurrence of selected wastewater compounds in the Big Sioux River Basin upstream from Sioux Falls. The city of Sioux Falls also conducts quarterly or annual monitoring of selected unregulated organic compounds in source and finished water (City of Sioux Falls, 2011).

\section{Methods of Study}

The study approach included the collection of water samples from source and finished water in the Sioux Falls area for the analyses of AOCs, nutrients, and nitrogen and oxygen isotopes in nitrate. Fifteen samples of source water and 11 samples of finished water were collected over a range of hydrologic conditions during an 18-month period (table 2). This section of the report describes the sampling sites, sample collection and analysis methods, and associated laboratory and field quality assurance/quality control used in this study.

Water-quality constituents monitored in this study were selected to represent a wide range of the compounds known or suspected to occur within the Big Sioux River Basin. These include AOCs and selected nutrients that may have anthropogenic and natural origins. Stable isotopes of nitrogen and oxygen in nitrate also were used to help identify probable sources of nitrate. In addition, selected physical properties were measured.

Table 2. Study sampling dates and source-water components used for day sampled.

[" $\mathrm{x}$ " indicates sample collected; shading denotes source-water components for day sampled]

\begin{tabular}{lccc}
\hline \multicolumn{1}{c}{ Date } & \multicolumn{2}{c}{ Source water } & $\begin{array}{c}\text { Finished water } \\
\text { (site }\end{array}$ \\
\cline { 2 - 3 } & $\begin{array}{c}\text { Big Sioux River } \\
\text { (s33600096442400) }\end{array}$ & $\begin{array}{c}\text { Groundwater } \\
\text { (site }\end{array}$ & $\begin{array}{c}\text { 433421096434401) } \\
\text { 433419096434200) }\end{array}$ \\
\hline $6 / 1 / 2009$ & $\mathrm{x}$ & & $\mathrm{x}$ \\
$6 / 30 / 2009$ & $\mathrm{x}$ & & $\mathrm{x}$ \\
$8 / 3 / 2009$ & $\mathrm{x}$ & $\mathrm{x}$ & $\mathrm{x}$ \\
$8 / 24 / 2009$ & $\mathrm{x}$ & & $\mathrm{x}$ \\
$11 / 4 / 2009$ & & $\mathrm{x}$ & $\mathrm{x}$ \\
$1 / 4 / 2010$ & $\mathrm{x}$ & $\mathrm{x}$ & \\
$1 / 5 / 2010$ & & $\mathrm{x}$ & $\mathrm{x}$ \\
$2 / 17 / 2010$ & & $\mathrm{x}$ & $\mathrm{x}$ \\
$3 / 25 / 2010$ & $\mathrm{x}$ & $\mathrm{x}$ & $\mathrm{x}$ \\
$6 / 9 / 2010$ & $\mathrm{x}$ & $\mathrm{x}$ & $\mathrm{x}$ \\
$7 / 29 / 2010$ & & 7 & $\mathrm{x}$ \\
$8 / 26 / 2010$ & $\mathrm{x}$ & & $\mathrm{x}$ \\
\hline Total number & 8 & & 11 \\
of samples & & & \\
\hline
\end{tabular}




\section{Sampling Sites}

Two source-water sites and one finished-water site were sampled during this study (fig. 1). One source-water site was the Big Sioux River (USGS site 433600096442400) at an intake just upstream from the diversion dam. The other source-water site (USGS site 433421096434401) was blended groundwater from multiple wells and collection galleries producing from the Big Sioux, Skunk Creek, and Split Rock Creek aquifers (fig. 4). Contributions of individual wells and galleries to the blended groundwater samples were not determined. Finished water (USGS site 433419096434200) was collected from a water line following water treatment but prior to distribution. During periods of high demand, surface water from the Big Sioux River undergoes a high-rate clarification process prior to blending with the raw groundwater. After blending, the water-treatment process is the same regardless of the presence of surface water, which includes conventional lime softening, re-carbonation, filtration, fluoridation, and disinfection and uses granular and powdered activated carbon in separate treatment steps (City of Sioux Falls, 2011). The treatment process is not designed to remove trace organic compounds.

\section{Collection, Processing, and Analysis of Water Samples}

Water-quality and isotope samples were collected according to standard USGS procedures (U.S. Geological Survey, variously dated; U.S. Geological Survey, Reston Stable Isotope Laboratory, 2008). All samples of raw groundwater and finished water were collected directly from flowing water lines. Raw surface water from the Big Sioux River was collected from a flowing water line when this source was being used for water supply. For sampling dates when the Big Sioux River was not being used as a source for water supply, samples were collected directly from the river using depthintegrating techniques at the screened intake along the bank just upstream from the diversion dam. Sample-collection techniques follow procedures described in detail in chapters A4 and A5 of the USGS National Water-Quality Field Manual (U.S. Geological Survey, variously dated). Equipment used in the collection and processing of samples analyzed for AOCs were composed of Teflon ${ }^{\circledR}$, baked amber glass, high-density polyethylene (HDPE) plastic, or stainless steel and were rigorously cleaned according to standard USGS procedures. Equipment used in the collection and processing of samples analyzed for nutrients or stable isotopes of nitrogen and oxygen were composed of Teflon ${ }^{\circledR}$, HDPE, or stainless steel. For all AOC laboratory analyses of finished water, samples were preserved with ascorbic acid or sodium thiosulfate to prevent degradation of organic compounds in the presence of free chlorine (U.S. Environmental Protection Agency, 2011a; Valder and others, 2008).
Samples for analyses of selected AOCs were filtered in the field using a 142-millimeter diameter stainless steel plate-filter assembly with 0.7 -micrometer nominal pore size glass-fiber filter media and a valveless ceramic-piston pump. Samples for the analyses of nutrients and stable isotopes were filtered using a 0.45 -micrometer pore size HDPE capsule filters and a peristaltic pump. Stable-isotope samples were further filtered using 0.2-micrometer pore size cellulose acetate membrane filters. Following collection and processing of samples for analyses of AOCs, nutrients, and stable isotopes, samples were packaged, placed on ice, and shipped to respective laboratories for analyses. Information on the measurement, laboratory analyses, and applicable humanhealth benchmarks of the constituents analyzed for this study follow.

\section{Physical Properties}

Physical properties of $\mathrm{pH}$, specific conductance, water temperature, and dissolved oxygen were measured continuously during the spring and summer months from March 2009 to September 2010 at USGS streamgage 06481000 using an in-situ multi-parameter sonde according to standard USGS procedures (Wagner and others, 2006). The physical properties also were measured in the samples of source water and finished water on each sampling date using a multi-parameter sonde and flow-through chamber (U.S. Geological Survey, variously dated).

\section{Anthropogenic Organic Compounds}

Organic compounds that are derived from anthropogenic sources (such as wastewater discharges or agricultural runoff) and found in water samples can be used to infer potential sources of contaminants from a drainage basin. Samples were analyzed for $184 \mathrm{AOCs}$, including 16 compounds analyzed by multiple analytical methods. The compounds listed in appendix 1 are organized by an analytical method number, which generally contains similar compounds in terms of their typical source or use.

Analytical method 1 includes 64 major agricultural herbicides, insecticides, and selected degradates, including three major herbicides (atrazine, metolachlor, and acetochlor) widely used in the Big Sioux River Basin upstream from Sioux Falls (U.S. Department of Agriculture, 2012). Laboratory analyses for this method were performed at the USGS National Water Quality Laboratory (NWQL) in Lakewood, Colo., using solid-phase extraction (SPE) columns that contain octadecyl-bonded porous silica to extract the analytes. The columns are dried by using nitrogen gas, and adsorbed analytes are eluted with ethyl acetate. Extracted analytes are determined by capillary-column gas chromatography/ mass spectrometry (Sandstrom and others, 2001; Madsen and others, 2002). 
Analytical method 2 includes 14 pharmaceuticals predominantly used by humans and that can be found in municipal wastewater discharges. Laboratory analyses for this method were conducted at NWQL using a chemically modified styrene-divinylbenzene resin-based SPE cartridge for analyte isolation and concentration, followed by a highperformance liquid chromatography/mass spectrometry system to separate the pharmaceuticals of interest from each other and coextracted material (Furlong and others, 2008).

Analytical method 3 includes 69 compounds from a broad range of sources including those typically found in wastewater effluents (sterol compounds and household and industrial products), agricultural runoff (herbicides and insecticides), and urban runoff (polycyclic aromatic hydrocarbons). Laboratory analyses of compounds in analytical method 3 were conducted at NWQL using extraction with continuous liquid-liquid extractors and methylene chloride solvent and then determined by capillary-column gas chromatography/ mass spectrometry (Zaugg and others, 2006).

Analytical method 4 includes 33 human and veterinary antibiotics and degradates that can be found in human and animal wastes. Laboratory analyses of compounds in analytical method 4 were conducted at the USGS Kansas Organic Geochemistry Research Laboratory (OGRL) in Lawrence, Kans., using automated SPE and liquid chromatography/ tandem mass spectrometry (Meyer and others, 2007).

Analytical method 5 includes 16 steroid hormones produced by warm-blooded animals and 4 other compounds that can be found in wastewater discharges or animal wastes. Laboratory analysis for analytical method 5 is currently (2011) under development at NWQL; an expanded method description is provided in appendix 2. Analytical methods 3 and 5 were performed on unfiltered samples, whereas all others were performed on field-filtered samples.

AOC concentrations detected below the lowest daily standard, or for information-rich methods, concentrations detected below the long-term method detection level (LTMDL), are reported as estimated concentrations (Childress and others, 1999), coded with an "E" preceding the concentration. The laboratory reporting level (LRL) generally is equal to twice the yearly determined LT-MDL (Childress and others, 1999). The LT-MDL is a detection level derived by determining the standard deviation or a minimum of 24 method detection level spike-sample measurements throughout an extended time. The LT-MDL data are collected on a continuous basis to assess year-to-year variations in the LT-MDL. The chance of falsely reporting a concentration at or greater than the LT-MDL for a sample that did not contain the analyte is predicted to be less than or equal to 1 percent (Childress and others, 1999). Also, at low concentrations, especially concentrations less than the LRL, the variability of detection is high, false negatives are more likely, and greater variability in reported concentrations is expected (Martin, 2002). Results for analytical methods 1 and 3 also contain concentrations reported as "M," which indicates the presence of the compound was verified but not quantified. In most cases, results coded as "M" were detected at concentrations less than the LT-MDL and do not round to the LT-MDL using the significant figures signified by the LRL. The reporting of these data is subject to the discretion of the laboratory analyst (David Mueller, U.S. Geological Survey, written comm., 2011). Concentrations are reported as less than the LRL when the compound was not detected.

Appendix 1 also lists relevant U.S. Environmental Protection Agency (USEPA) Maximum Contaminant Levels (MCLs) and USGS Health-Based Screening Levels (HBSLs). The HBSLs are benchmark concentrations of contaminants in water that may be of potential concern for human health, if exceeded. The HBSLs are non-enforceable benchmarks developed by the USGS in collaboration with the USEPA and others using (1) USEPA Office of Water methodologies for establishing drinking-water guidelines, and (2) the most recent USEPA peer-reviewed, publicly available humanhealth toxicity information (Toccalino, 2007). MCLs are available for 8 AOCs, HBSLs are available for 32 AOCs, and no applicable water-quality benchmarks are available for the remaining 144 AOCs.

\section{Nutrients and Nitrogen and Oxygen Isotope Ratios in Nitrate}

Selected nutrients (nitrate, nitrite, ammonia, and orthophosphate) were used to examine the variability of potential contaminant sources to the water supply in the Sioux Falls area. Nitrate originates from a variety of anthropogenic and natural sources, including wastewater, synthetic fertilizers, animal wastes, explosives, and decomposing organic matter (Clark and Fritz, 1997). In standard analytical techniques, nitrate and its intermediate transformation species, nitrite, are measured together. Concentrations of nitrite plus nitrate $\left(\mathrm{NO}_{2}+\mathrm{NO}_{3}\right)$ in finished water are regulated by the USEPA MCL of 10 milligrams per liter as nitrogen $(\mathrm{mg} / \mathrm{L}$ as $\mathrm{N})$. $\mathrm{NO}_{2}+\mathrm{NO}_{3}$ concentrations greater than $10 \mathrm{mg} / \mathrm{L}$ as $\mathrm{N}$ may be injurious when used in feeding infants (U.S. Environmental Protection Agency, 2009). Ammonia and orthophosphate were used as supplementary measures of nutrient enrichment in the source water. Samples were analyzed for nutrients at NWQL using standard methods (Fishman, 1993). City of Sioux Falls personnel assisted in the collection of five source-water samples for nutrients and nitrogen and oxygen isotope ratios in nitrate following short-duration storms when USGS personnel could not collect samples. Laboratory analyses of $\mathrm{NO}_{2}+\mathrm{NO}_{3}$ for these samples were performed by the City of Sioux Falls Purification Plant Laboratory using ion chromatography according to standard methods (American Public Health Association, 2005).

Ratios of the stable isotopes of nitrogen $\left({ }^{15} \mathrm{~N}\right.$ and $\left.{ }^{14} \mathrm{~N}\right)$ and oxygen $\left({ }^{18} \mathrm{O}\right.$ and $\left.{ }^{16} \mathrm{O}\right)$ in nitrate can provide insights on the sources in water (typically differentiating fertilizer from animal waste or organic matter). The additional neutrons in ${ }^{15} \mathrm{~N}$ and ${ }^{18} \mathrm{O}$ result in atomic weights for these isotopes that 
are different from those of the more predominant isotopes ${ }^{14} \mathrm{~N}$ and ${ }^{16} \mathrm{O}$. Molecules with different atomic weights have different reaction rates, which leads to isotope partitioning or fractionation (Clark and Fritz, 1997). Stable isotope ratios are expressed in "delta notation," which compares the ratio between the heavy and light isotopes of a sample to that of a reference standard. Delta values are expressed as a difference, in parts per thousand, or per mil (\%), from the value reference standard. The nitrogen isotope ratio $\left(\delta^{15} \mathrm{~N}\right)$ of a sample written in delta notation is:

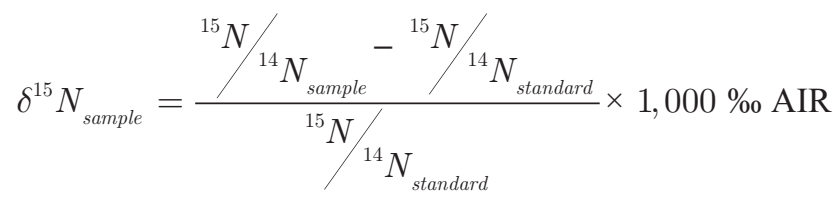

The oxygen isotope ratio $\left(\delta^{18} \mathrm{O}\right)$ of a sample written in delta notation is expressed by replacing ${ }^{15} \mathrm{~N}$ and ${ }^{14} \mathrm{~N}$ with ${ }^{18} \mathrm{O}$ and ${ }^{16} \mathrm{O}$, respectively, and atmospheric nitrogen (AIR) with Vienna Standard Mean Ocean Water (VSMOW) in equation 1.

The manufacture of fertilizer results in very little fractionation; therefore, $\delta^{15} \mathrm{~N}$ of synthetic mineralized fertilizer is about 0 \%o (Clark and Fritz, 1997; Böhlke, 2002). Organic nitrogen fixation of soil organic matter has a minor fractionation effect on ${ }^{15} \mathrm{~N}$, resulting in enrichment of about 3-7 \%o. The complex fractionation of ${ }^{15} \mathrm{~N}$ through the food web results in enriched $\delta^{15} \mathrm{~N}$ values in the waste from animals of about 10-20 \%o (Clark and Fritz, 1997). Biologically formed nitrate generally is depleted in ${ }^{18} \mathrm{O}$ because only one oxygen atom comes from atmospheric oxygen with the remaining two molecules coming from water (Hollocher, 1984), which is considerably more depleted in ${ }^{18} \mathrm{O}$. The oxygen in synthetic fertilizer is primarily from atmospheric oxygen. The $\delta^{18} \mathrm{O}$ values for nitrate vary according to the $\delta^{18} \mathrm{O}$ of local waters, so absolute ranges cannot be estimated. Isotopic composition of nitrate and oxygen was analyzed at the Reston Stable Isotope Laboratory (RSIL, in Reston, Va.) by using mass spectrometry to analyze the conversion of nitrate to nitrous oxide (Révész and Casciotti, 2007).

\section{Quality Assurance / Quality Control}

Quality-control samples were collected to identify possible cases of random or systemic errors in the field sampling, shipping, and laboratory analyses. Field-equipment blank samples and sequential replicate samples were used to determine the potential for sample contamination. Environmental matrix spike samples were used to monitor the performance of a given analytical method for a specific environmental matrix.

Field-equipment blank samples were collected at sites used for collection of environmental samples by passing analyte-free water through the collection and processing equipment used for the environmental samples and by using procedures identical to those used to collect and process the environmental samples. Constituent concentrations less than the minimum reporting level (MRL) in field-equipment blank samples indicate that the overall process of sample collection, processing, and laboratory analysis was free of substantial contamination. The MRL is the lowest measured concentration of a constituent that may be reliably reported from the use of a given analytical method (Timme, 1995). Sporadic, infrequent detections at concentrations near the MRL probably represent contamination from sample collection, processing, or shipping that is not likely to cause bias in the study results. Consistent detections in the field-equipment blank samples at concentrations within the range of concentrations in the environmental samples indicate that environmental concentrations need to be qualified or omitted from study results.

Field-equipment blank samples were collected with 5 of the 26 environmental samples. Four different compounds were detected, all analyzed by analytical method 3. Two compounds - bis(2-ethylhexyl) phthalate (DEHP) and triphenyl phosphate - were detected in the groundwater blank sample collected on November 4, 2009. Triphenyl phosphate was not detected in the corresponding environmental sample, but the DEHP detection in the corresponding environmental sample was censored from additional statistical analyses; analytical results that were censored were removed from the dataset. The compound 4-nonylphenol was detected in the surface-water blank sample on January 4, 2010 (but was not detected in the corresponding environmental sample), and isophorone was detected in both finished-water blank samples on June 30, 2009, and November 4, 2009. On the basis of previous quality-control results (Sandstrom and Delzer, 2007), the compounds benzophenone, isophorone, and 4-nonylphenol were censored in all finished-water environmental samples because of systematic contamination with the dechlorination reagent and $\mathrm{pH}$ buffer used in these samples.

Precision of analytical results for field replicate samples may be affected by numerous sources of potential variability in field and laboratory processes, including sample collection, sample processing and handling, and laboratory preparation and analysis. Analyses of field replicate samples, therefore, can indicate the reproducibility of environmental data and provide information on the variability associated with sample collection and analysis. One field replicate sample was analyzed for nutrients (15 environmental samples), and all relative percent differences (difference in concentration divided by mean concentration for the environmental/replicate pair) were less than 1 percent.

Environmental matrix spike samples consist of replicate samples that are collected and processed identically to the primary environmental sample but are fortified with known concentrations of method analytes at the laboratory. Concentrations of the method analytes in the primary environmental samples and matrix spikes are determined, and the ambient concentrations in the primary environmental sample are subtracted from the matrix-spike concentrations. The resulting 
concentrations are compared to the expected concentrations to calculate the percent recoveries for the method analytes using the following equation:

$$
\text { Percent recovery }=\left(C_{\text {spiked }}-C_{\text {unspiked }}\right) * 100 /\left[\left(C_{\text {soln }} * A m t\right) / \text { Vol }\right]
$$

where

$$
\begin{gathered}
C_{\text {spiked }} \quad \begin{array}{l}
\text { is the measured concentration of the spiked } \\
\text { sample, }
\end{array} \\
C_{\text {unspiked }} \quad \begin{array}{c}
\text { is the measured concentration of the unspiked } \\
\text { sample, }
\end{array} \\
C_{\text {soln }} \text { is the concentration of the spike solution, } \\
A m t \quad \text { is the amount of spike added, and } \\
\mathrm{Vol} \text { is the sample volume. }
\end{gathered}
$$

If $C_{\text {unspiked }}$ is less than the LRL, a value of zero is used for this concentration. Recoveries less than 100 percent indicate loss (or transformation) of the target analyte during the sampleprocessing period, and recoveries greater than 100 percent indicate gain of the target analyte. The satisfactory range of median percent recoveries for environmental matrix spike samples typically is between $50-120$ percent (Sando and others, 2006).

Matrix spike samples were collected with 5 of the 26 environmental samples. Percent recoveries for all matrix spike samples are shown in appendix 3. Recovery results indicated limited potential for loss or gain of target analytes during the field and laboratory processing for 85 percent of compounds, and no adjustment of analyte concentrations was made on the basis of unsatisfactory percent recoveries. For analytical method 1, five compounds had median percent recoveries less than 50 percent, 9 compounds had median recoveries greater than 120 percent, and the remaining 50 compounds had median percent recoveries within the satisfactory range. Median percent recoveries were less than 50 percent for 2 of the 14 analytes in analytical method 2 and for 9 of the 69 analytes in analytical method 3. Six analytes in analytical method 4 had median percent recoveries greater than 120 percent. All matrix recoveries were satisfactory for analytical method 5 .

\section{Occurrence of Anthropogenic Organic Compounds and Nutrients}

Water-quality results are presented in separate sections for AOCs and nutrients. The occurrence of AOCs is presented according to the sampling sites (surface-water source, groundwater source, and finished water). The occurrence of nutrients is presented for source-water samples (not collected for finished water) and includes ratios of nitrogen and oxygen isotopes in nitrate. For brevity, sampling sites for the Big Sioux River, blended groundwater from multiple wells and collection galleries, and finished water (USGS sites 433600096442400, 433421096434401, and 433419096434200 , respectively) will be referred to as the Big Sioux River, groundwater, and finished-water sites for the remainder of this report.

\section{Physical Properties}

The physical water-quality properties of $\mathrm{pH}$, specific conductance, water temperature, and dissolved oxygen provide an initial characterization of water quality. The daily mean water temperature and specific conductance collected continuously from March 2009 to September 2010 at the Big Sioux River near Dell Rapids (USGS streamgage 06481000; U.S. Geological Survey, 2011), which is upstream from Sioux Falls (inset map in fig. 1), are shown on figure 5. Data for the physical water-quality properties for samples collected at source-water and finished-water sites are presented in appendix 4. Large increases in specific conductance indicate an increase in the dissolved solids concentration, which may correlate positively with concentrations of certain nutrients and AOCs associated with the same sources as the dissolved solids. Specific conductance and streamflow usually are inversely related in the Big Sioux River. Immediately following precipitation events in the Big Sioux River Basin, specific conductance typically decreases as a result of the precipitation with low dissolved solids entering the rivers. Shortly after the June 9 and August 24, 2010, sampling dates, prolonged rainfall events caused a rise in streamflow and groundwater levels (fig. 2), and the dilution of dissolved solids because of the precipitation is shown by the decrease in specific conductance following these sampling dates (fig. 5). Commonly, this decrease in specific conductance is followed by an increase during the subsequent weeks as the rainwater is replaced by surface runoff that has traveled farther distances from the river and contains various contaminants and dissolved solids accumulated along the way. Groundwater discharge into the river also could increase the specific conductance following storms, as groundwater with higher values of specific conductance mix with the snowmelt or runoff with lower values of specific conductance. For example, in the month following the snowmelt sample on March 25, 2010, specific conductance increased as the streamflows decreased (figs. 2 and 5). Water temperature typically follows the same pattern as specific conductance in the spring and summer because precipitation commonly is cooler than the antecedent river temperature. Other than the March 25, 2010, snowmelt sample, samples were collected from the Big Sioux River during base-flow conditions (fig. 2); no samples were representative of the conditions following spring and summer rainfall events when the probability of detecting higher concentrations of surfacerunoff contaminants (such as pesticides) is greater. 


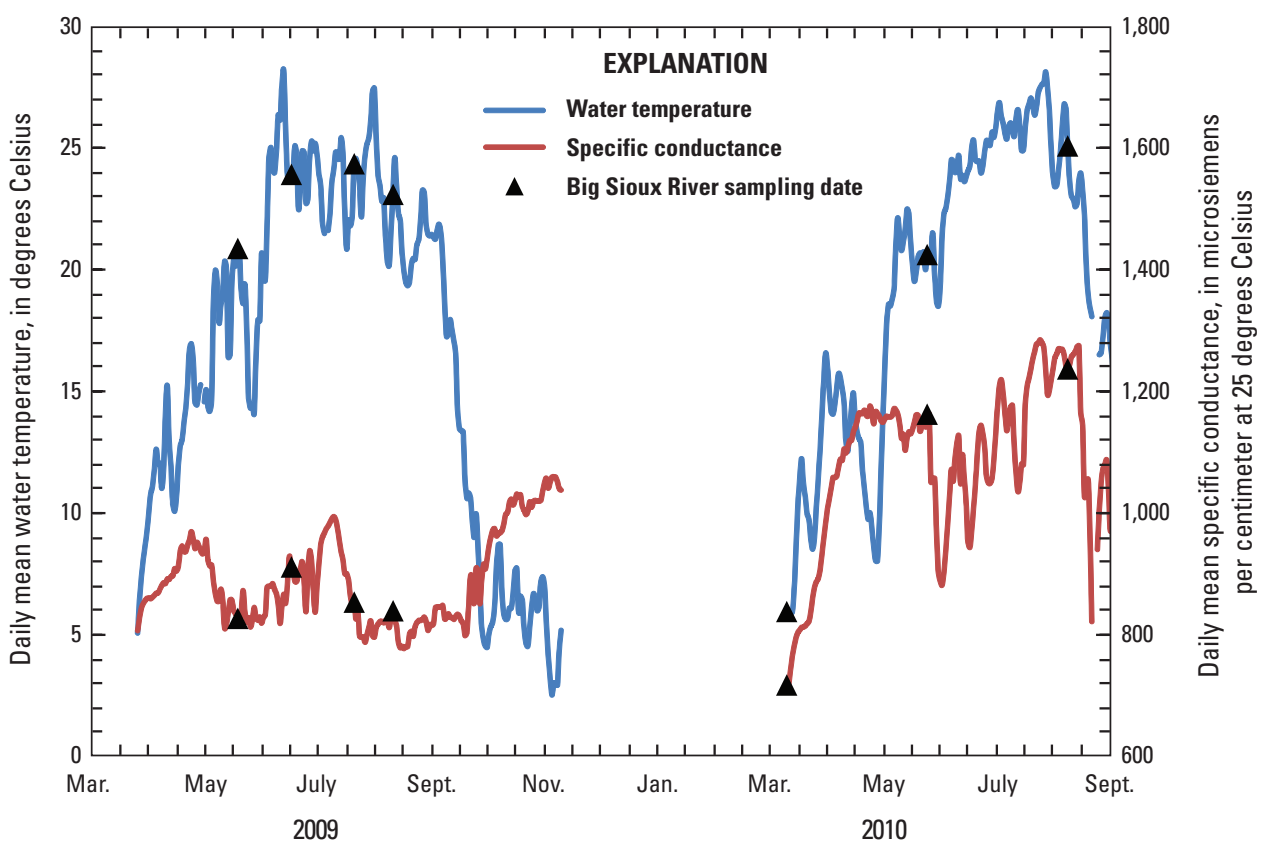

Figure 5. Daily mean water temperature and specific conductance at the Big Sioux River near Dell Rapids (streamgage 06481000), March 2009 to September 2010.

\section{Anthropogenic Organic Compounds}

The occurrence of AOCs is characterized separately for the Big Sioux River (source water), groundwater (source water), and finished water. The AOC concentrations for all samples are presented in appendix 4. Data that were censored because of potential contamination as indicated by qualityassurance samples were removed from the dataset and coded with a "C" in appendix 4. Data for all 184 AOCs are not available for every sample collected because a few bottles were broken during shipment to the laboratory and because some constituents were not analyzed in some samples because of laboratory quality-assurance issues. For the 184 AOCs analyzed, 45 compounds ( 24 percent) were detected in at least one sample of source or finished water (appendix 4), and 13 compounds were detected in at least 20 percent of all samples (table 3). Concentrations of AOCs detected were all less than 1 microgram per liter $(\mu \mathrm{g} / \mathrm{L})$, except for cholesterol and beta-sitosterol concentrations in the Big Sioux River, and one detection of DEHP in finished water. More than 75 percent of the detections of AOCs were at concentrations less than $0.1 \mu \mathrm{g} / \mathrm{L}$. Concentrations coded as " $\mathrm{M}$ " in appendix 4 and table 3 indicate the presence of the analyte was verified but at a concentration less than reporting levels and could not be quantified.

To aid in evaluating water-quality data in the context of human health, benchmark quotient (BQ) values were calculated (Toccalino, 2007). A BQ value is the ratio of a measured concentration of a detected compound to its MCL or HBSL (BQ values cannot be calculated for compounds without a relevant human-health benchmark). For this study, the maximum concentration detected for each compound was used to calculate this ratio, called BQmax. A BQmax value greater than or equal to 0.1 (within an order of magnitude of the benchmark) was used to identify compounds that may merit additional study and to provide an early indication of contaminant concentrations of potential human-health concern.

\section{Big Sioux River}

Eight source-water samples were collected from the Big Sioux River. A total of 33 different AOCs were detected in at least one sample from the Big Sioux River (appendix 4), and 20 compounds were detected in at least 20 percent of the samples (table 3 ). Five compounds (atrazine, cholesterol, deethylatrazine, metolachlor, and prometon) were detected in every sample. For atrazine, the maximum concentration was about an order of magnitude less than its benchmark standard (table 3). Maximum concentrations of metolachlor and prometon were about four orders of magnitude less than benchmark standards (table 3). Cholesterol concentrations in the Big Sioux River ranged from $0.630 \mu \mathrm{g} / \mathrm{L}$ in the winter low-flow sample on January 4, 2010, to $11.5 \mu \mathrm{g} / \mathrm{L}$ in the late summer sample collected on August 3, 2009. The presence of cholesterol may be indicative of wastewater or livestock-waste runoff. The pesticide acetochlor was detected in 6 of 8 samples from the Big Sioux River; the maximum detected concentration of $0.146 \mu \mathrm{g} / \mathrm{L}$ was within an order of magnitude of the HBSL.

\section{Groundwater}

Seven source-water samples were collected from groundwater. A total of 30 different AOCs were detected in at least one groundwater sample (appendix 4), and 14 compounds were detected in at least 20 percent of groundwater samples (table 3). The same four herbicides or degradates detected in all Big Sioux River samples (atrazine, deethylatrazine, 
Table 3. Detection frequency, maximum concentration, and maximum benchmark quotient for anthropogenic organic compounds detected in at least 20 percent of samples at any site.

[Big Sioux River, site 433600096442400; Groundwater, site 433421096434401; finished water, site 433419096434200; USEPA, U.S. Environmental Protection Agency; MCL, Maximum Contaminant Level; USGS, U.S. Geological Survey; HBSL, Health-Based Screening Level; $\mu \mathrm{g} / \mathrm{L}$, micrograms per liter; BQmax, maximum benchmark quotient; --, not available; E, estimated value; M, presence verified but not quantified]

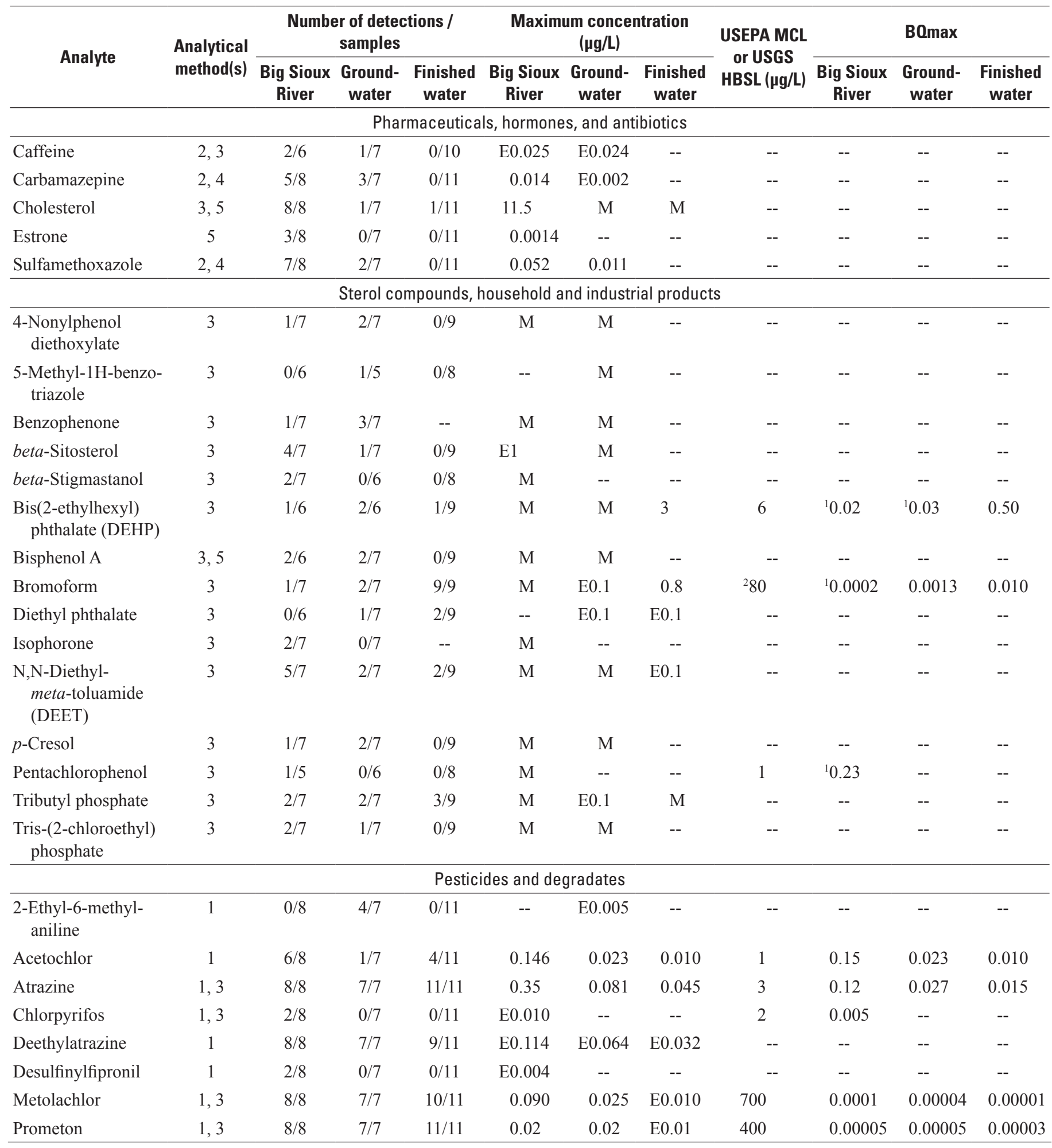

${ }^{1}$ Actual concentration used in BQmax calculation has high uncertainty and is not shown in appendix 4.

${ }^{2} \mathrm{MCL}$ is for total trihalomethanes. 
metolachlor, and prometon) also were detected in all groundwater samples. Atrazine concentrations in the groundwater ranged from $0.008 \mu \mathrm{g} / \mathrm{L}$ in the winter (Febuary 17, 2010) to $0.081 \mu \mathrm{g} / \mathrm{L}$ in the summer (July 29, 2010). Deethylatrazine was detected at similar concentrations, from 0.008 $0.064 \mu \mathrm{g} / \mathrm{L}$. Metolachlor was detected in the groundwater at a concentration range of $0.005-0.025 \mu \mathrm{g} / \mathrm{L}$. Similar to the Big Sioux River concentrations, prometon concentrations for all groundwater samples were $0.02 \mu \mathrm{g} / \mathrm{L}$ or less.

\section{Finished Water}

Eleven finished-water samples were collected. A total of 14 AOCs were detected in at least one finished-water sample (appendix 4), and 9 compounds were detected in at least 20 percent of samples (table 3). The disinfection byproduct bromoform was detected in every finished-water sample, along with the herbicides atrazine and prometon. Bromoform concentrations ranged from 0.6 to $0.8 \mu \mathrm{g} / \mathrm{L}$, which were much less than the MCL of $80 \mu \mathrm{g} / \mathrm{L}$ for total trihalomethanes (including bromoform). Atrazine concentrations in finished water were similar to those in groundwater (the dominant source water), ranging from $0.008-0.045 \mu \mathrm{g} / \mathrm{L}$. Similar to the source-water concentrations, prometon concentrations in finished water were $0.01 \mu \mathrm{g} / \mathrm{L}$ or less. The relatively high concentration of DEHP in finished water on November 4, $2009(3 \mu \mathrm{g} / \mathrm{L})$ occurred on the same day the compound was detected in both the groundwater and blank sample associated with the groundwater sample. The DEHP concentration in the groundwater sample was not high enough to be quantified and was censored in appendix 4 because of the detection in the blank sample. The concentration in the groundwater blank sample was at a similar concentration $(2 \mu \mathrm{g} / \mathrm{L})$ as the finished-water sample. DEHP was detected in three other source-water samples and was not detected in the blank sample associated with the finished-water sample.

\section{Nutrients}

Nutrient samples were collected only at source-water sites (Big Sioux River and groundwater). Concentrations of nutrients and nitrogen and oxygen isotope ratios in nitrate for the source-water samples are presented in table 4. Nutrient concentrations varied seasonally in samples from the Big Sioux River and groundwater. The $\mathrm{NO}_{2}+\mathrm{NO}_{3}$ concentrations generally were lower in groundwater than the Big Sioux River, but ammonia concentrations typically were higher in groundwater than in the Big Sioux River. The $\mathrm{NO}_{2}+\mathrm{NO}_{3}$ concentrations in the Big Sioux River were lower in 2009-10 than in previous years (Tim Stefanich, city of Sioux Falls, written comm., 2010), and were always less than one-half of the MCL for drinking water $(10 \mathrm{mg} / \mathrm{L}$ as $\mathrm{N})$. In the Big Sioux River, $\mathrm{NO}_{2}+\mathrm{NO}_{3}$ concentrations were typically less than $1 \mathrm{mg} / \mathrm{L}$ as $\mathrm{N}$ for the summer months in 2009, increased to nearly $3 \mathrm{mg} / \mathrm{L}$ as $\mathrm{N}$ by January 2010, reached a maximum of $4.06 \mathrm{mg} / \mathrm{L}$ as $\mathrm{N}$ following a June 2010 runoff event, and decreased to $0.123 \mathrm{mg} / \mathrm{L}$ as $\mathrm{N}$ by August 2010. For groundwater, $\mathrm{NO}_{2}+\mathrm{NO}_{3}$ concentrations increased from $0.129 \mathrm{mg} / \mathrm{L}$ as $\mathrm{N}$ in November 2009 to $0.701 \mathrm{mg} / \mathrm{L}$ as $\mathrm{N}$ in March 2010, and then decreased to less than $0.100 \mathrm{mg} / \mathrm{L}$ as $\mathrm{N}$ in the summer months of 2010. During the fall and summer months, ammonia concentrations were greater than $\mathrm{NO}_{2}+\mathrm{NO}_{3}$ concentrations in groundwater samples. Orthophosphate concentrations generally were stable in the groundwater samples ranging between 0.010 and $0.020 \mathrm{mg} / \mathrm{L}$ as phosphorus. Orthophosphate concentrations were more variable in Big Sioux River samples than groundwater samples, ranging from $0.035 \mathrm{mg} / \mathrm{L}$ or less in the summer months of 2009 to $0.224 \mathrm{mg} / \mathrm{L}$ in the snowmelt sample collected in March 2010.

Isotopic ratios also varied seasonally in samples from the Big Sioux River but were somewhat less variable in groundwater samples (fig. 6). The $\delta^{15} \mathrm{~N}$ values for the Big Sioux River samples decreased from about 18.55 to $13.12 \%$ from June to July 2009, and reached a minimum value of $7.55 \%$ in the March 2010 snowmelt sample. From June to August 2010, the $\delta^{15} \mathrm{~N}$ values in the Big Sioux River samples increased from 9.36 to $21.59 \%$. Nitrogen and oxygen isotope ratios could not be determined for the June 1, August 3, and August 24, 2009 , samples from the Big Sioux River because the concentrations of $\mathrm{NO}_{2}+\mathrm{NO}_{3}$ were less than analytical reporting levels. The $\delta^{18} \mathrm{O}$ values mirrored the $\delta^{15} \mathrm{~N}$ values, as shown by the strong linear relation in figure 7. Groundwater $\delta^{15} \mathrm{~N}$ values were about $17-18 \%$ during the winter months (November 2009 to February 2010), but reached a maximum value of $22.84 \%$ on June 9,2010 , just prior to the sustained wet period in the summer of 2010. The late summer (July and August 2010) $\delta^{15} \mathrm{~N}$ values (10.54 and $13.22 \%$, respectively) in groundwater were lower than other groundwater samples.

\section{Implications of Occurrence}

Eight compounds were detected that have a human-health benchmark (USEPA MCL or USGS HBSL) that can be used to evaluate the concentrations in a human-health context. A plot of the BQmax for these compounds (fig. 8) shows no detections were at concentrations greater than relevant benchmarks (BQmax values were all less than 1). Four compounds had BQmax values greater than 0.1 (within an order of magnitude of the benchmark), indicating that additional monitoring of the compound may be warranted. Atrazine was detected at a maximum concentration of $0.35 \mu \mathrm{g} / \mathrm{L}(\mathrm{BQmax}=0.12)$ in the Big Sioux River, but BQmax values in groundwater and finished-water samples were less than 0.03 . The occurrence of atrazine is not uncommon, as atrazine was detected in all samples at all sites during this study, and was detected in more than 50 percent of Big Sioux River samples during 2001-04 with a higher LRL $(0.5 \mu \mathrm{g} / \mathrm{L}$; Sando and others, 2006) than those used during this study $(0.007$ and $0.2 \mu \mathrm{g} / \mathrm{L})$. Acetochlor had a BQmax value greater than 0.1 in Big Sioux River samples, but the BQmax value in finished water was two orders of magnitude less than the benchmark. Acetochlor was detected in 75 percent of the Big Sioux River samples, but in 
Table 4. Concentrations of nutrients and nitrogen and oxygen isotope ratios in nitrate in source water.

$[\mathrm{mg} / \mathrm{L}$, milligrams per liter; $\mathrm{N}$, nitrogen; $\mathrm{P}$, phosphorus; per mil, difference in parts per thousand from value reference standard; E, estimated value; <, less than; --, not available]

\begin{tabular}{|c|c|c|c|c|c|c|c|}
\hline Source water & Date & $\begin{array}{l}\text { Nitrogen, } \\
\text { ammonia, } \\
\text { dissolved } \\
\text { (mg/L as } \mathrm{N}) \\
\text { (00608) }\end{array}$ & $\begin{array}{l}\text { Nitrogen, } \\
\text { nitrite, } \\
\text { dissolved } \\
\text { (mg/L as N) } \\
\text { (00613) }\end{array}$ & $\begin{array}{l}\text { Nitrogen, nitrite } \\
\text { plus nitrate, } \\
\text { dissolved } \\
\text { (mg/L as N) } \\
\text { (00631) }\end{array}$ & $\begin{array}{l}\text { Orthophosphate, } \\
\text { dissolved } \\
\text { (mg/L as } \mathrm{P}) \\
(00671)\end{array}$ & $\begin{array}{c}\delta^{15} \mathrm{~N} \text { in nitrate } \\
\text { fraction, } \\
\text { water } \\
\text { (per mil) } \\
(82690)\end{array}$ & $\begin{array}{c}\delta^{18} 0 \text { in } \\
\text { nitrate } \\
\text { fraction, } \\
\text { water } \\
\text { (per mil) } \\
\text { (63041) }\end{array}$ \\
\hline \multirow{8}{*}{$\begin{array}{l}\text { Big Sioux River (site } \\
\quad 433600096442400 \text { ) }\end{array}$} & $6 / 1 / 2009$ & E0.011 & $<0.002$ & $<0.016$ & E0.005 & -- & -- \\
\hline & $7 / 10 / 2009$ & -- & -- & ${ }^{1} 1.08$ & -- & ${ }^{2} 15.55$ & ${ }^{2} 7.68$ \\
\hline & $7 / 14 / 2009$ & -- & -- & ${ }^{1} 1.13$ & -- & ${ }^{2} 13.12$ & ${ }^{2} 4.34$ \\
\hline & 8/3/2009 & $<0.02$ & $<0.002$ & $<0.016$ & 0.011 & -- & -- \\
\hline & $8 / 24 / 2009$ & $<0.02$ & $<0.002$ & $<0.016$ & 0.016 & -- & -- \\
\hline & $6 / 13 / 2010$ & -- & -- & 13.48 & -- & 29.36 & ${ }^{2} 4.03$ \\
\hline & $6 / 16 / 2010$ & -- & -- & ${ }^{1} 4.06$ & -- & ${ }^{2} 12.24$ & ${ }^{2} 5.87$ \\
\hline & $8 / 26 / 2010$ & $<0.02$ & 0.0057 & 0.123 & 0.189 & 21.59 & 12.35 \\
\hline \multirow{6}{*}{$\begin{array}{l}\text { Groundwater (site } \\
\quad 433421096434401 \text { ) }\end{array}$} & $11 / 4 / 2009$ & 0.245 & 0.0024 & 0.129 & 0.010 & 17.89 & 9.8 \\
\hline & $1 / 5 / 2010$ & 0.26 & 0.0081 & 0.363 & 0.019 & 16.95 & 6.16 \\
\hline & $2 / 17 / 2010$ & 0.248 & 0.0078 & 0.442 & 0.016 & 17.39 & 7.34 \\
\hline & $3 / 25 / 2010$ & 0.217 & 0.0085 & 0.701 & 0.019 & 14.45 & 7.12 \\
\hline & $6 / 9 / 2010$ & 0.192 & 0.0033 & 0.103 & 0.014 & 22.84 & 12.54 \\
\hline & $7 / 29 / 2010$ & 0.312 & 0.0029 & 0.092 & 0.017 & 10.54 & 5.15 \\
\hline
\end{tabular}

${ }^{1}$ Collection and laboratory analysis performed by city of Sioux Falls staff following short-duration storm.

${ }^{2}$ Collection performed by city of Sioux Falls staff following short-duration storm.

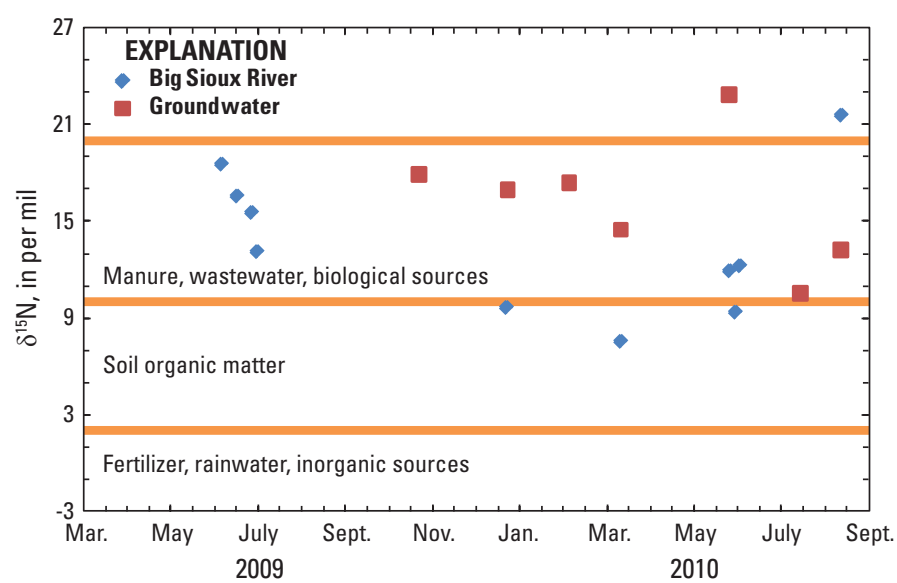

Figure 6. Nitrogen isotope ratios in nitrate for source-water samples in relation to the isotopic composition of nitrate sources, 2009-10.

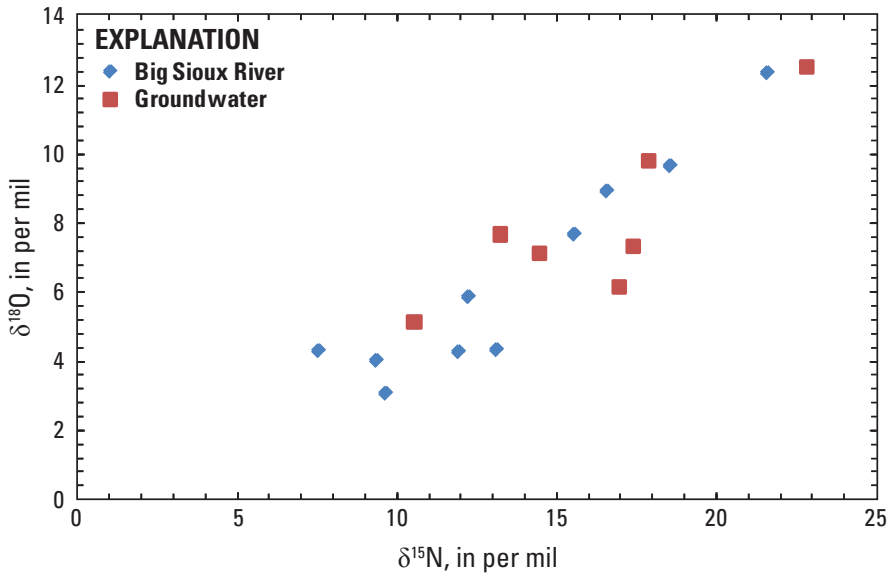

Figure 7. Nitrogen and oxygen isotope ratios in nitrate of sourcewater samples. 

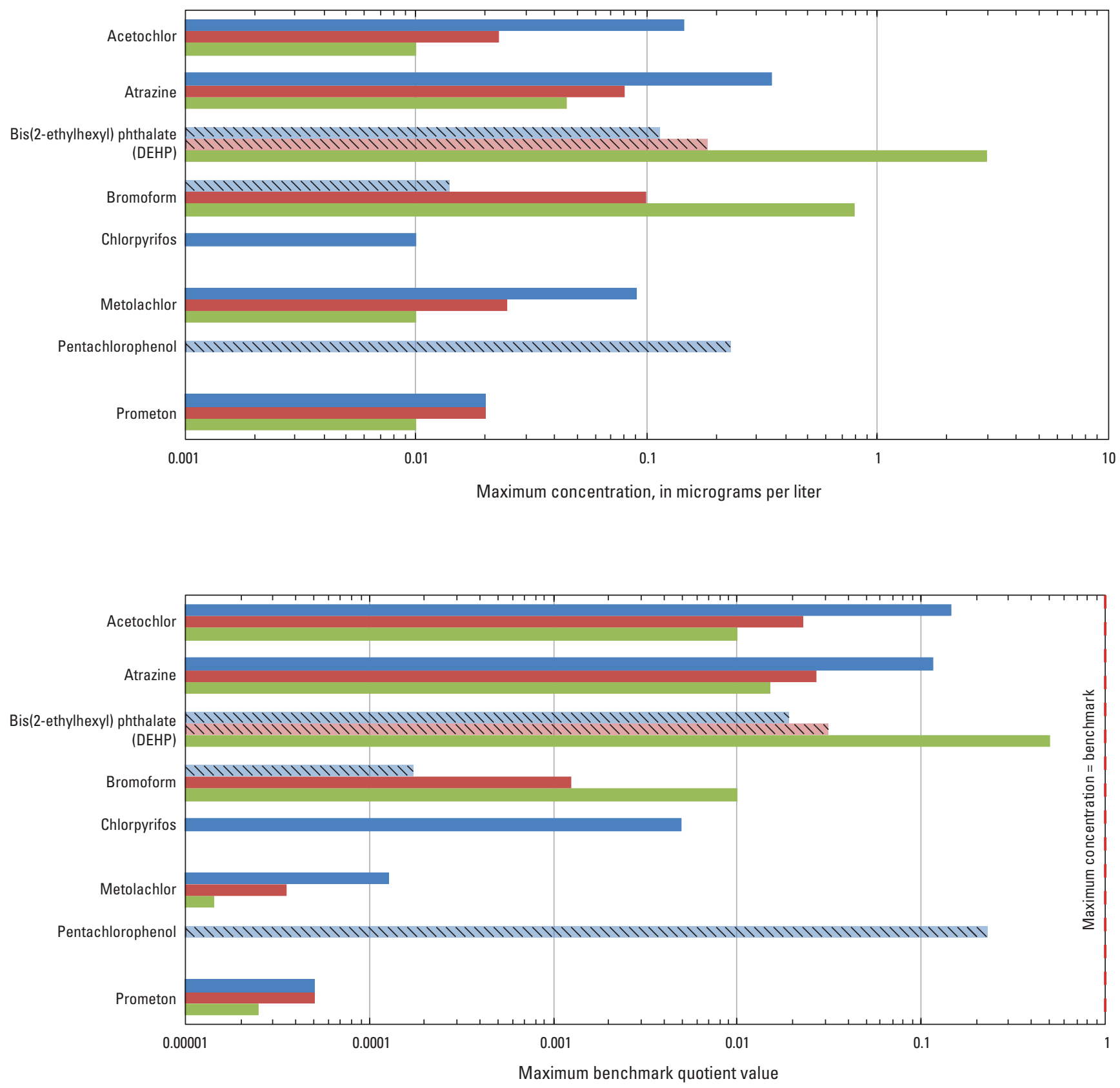

EXPLANATION

Big Sioux River

- Groundwater

Finished water

Figure 8. Maximum concentrations and benchmark quotient values for detected anthropogenic organic compounds that have a relevant benchmark. (Hatched bars for DEHP, bromoform, and pentachloraphenol indicate actual concentration was uncertain and not quantified in the text; presence of the compound was verified but not quantified). 
only 14 percent of the groundwater samples, indicating a more sporadic occurrence trend. Pentachlorophenol was detected in one of five samples in the Big Sioux River $(\mathrm{BQmax}=0.23)$, but was not detected in any sample of groundwater or finished water (three additional laboratory analyses of pentachlorophenol in the Big Sioux River were censored because of laboratory quality-control data). Pentachlorophenol was not detected in samples from the Big Sioux River and finished water in 2001-04, but was detected in two of six wastewater treatmentplant effluent samples (Sando and others, 2006). The plasticizer DEHP had the greatest BQmax value of any AOC (0.5) in finished water, but was not detected in any of the other eight finished-water samples and was detected in only 25 percent of the source-water samples. The compound was detected at a similar frequency (20 percent) in the Big Sioux River in 2001-04, and was detected at high concentrations (greater than $5 \mu \mathrm{g} / \mathrm{L}$ ) in samples of wastewater effluent (Sando and others, 2006). Although it is plausible that the finished-water detection represents the presence of DEHP, this detection is somewhat uncertain on the basis of the concentration $(2 \mu \mathrm{g} / \mathrm{L})$ in one of the four blank samples.

Three herbicides (atrazine, metolachlor, and prometon) and one degradate (deethylatrazine) were detected in finished water as frequently as in source water (table 3 ). The occurrence of herbicides in surface water for drainage basins with predominantly agricultural land use is not uncommon. Atrazine and metolachlor are two of the most heavily used agricultural herbicides in the United States with much of the use for corn production, and prometon has considerable use for weed control in areas not associated with agriculture such as on turf-grass, lawns, and roadsides (Gilliom and others, 2006). Previous studies indicate that the herbicide degradates (such as deethylatrazine) typically occur with their parent compounds at concentrations similar to or greater than concentrations of their parent compounds (Gilliom and others, 2006; Kingsbury and others, 2008), but not all potential degradates of atrazine, metolachlor, and prometon were analyzed as part of this study. The concentrations of herbicides in source water can vary by an order of magnitude from the period of peak application (early summer) to the winter months (fig. 9).

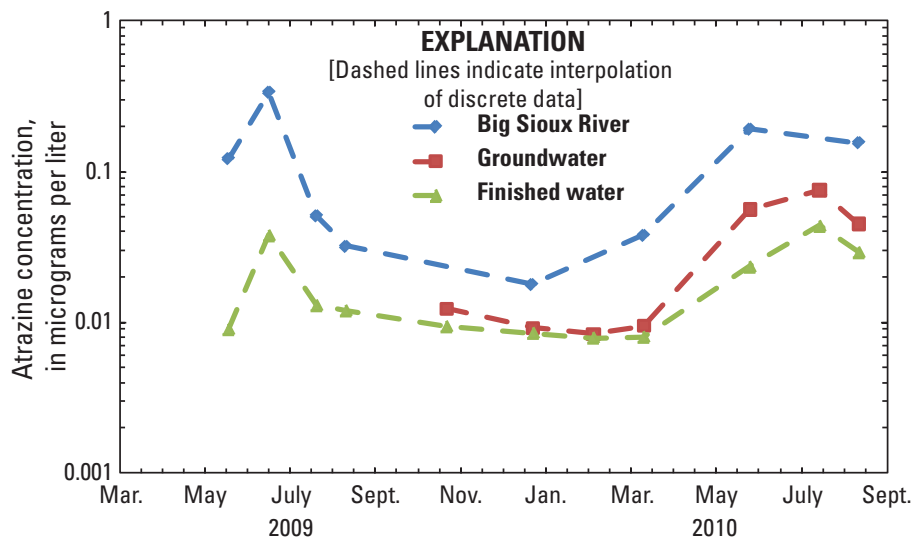

Figure 9. Atrazine concentration in source- and finished-water samples, 2009-10.
Chemical properties help explain the co-occurrence of certain AOCs in the Big Sioux River, groundwater, and finished water. The shallow setting of the Big Sioux aquifer provides a potential contaminant pathway to transport surface contaminants into the groundwater source because the Big Sioux River is hydraulically connected to the underlying aquifer in many areas. Atrazine, metolachlor, and prometon can be highly mobile in sandy soils and aquifers (Gilliom and others, 2006). Atrazine can remain in the environment for periods beyond the growing season when it was applied, with a half-life of about 60 days in the topsoil and substantially longer in the subsurface and aquatic environment (Christensen and Ziegler, 1998). These herbicides (along with acetochlor) have $\log$ octanol-water partitioning coefficients $\left(\log \mathrm{K}_{\text {ow }}\right)$ less than 5 (U.S. Environmental Protection Agency, 2011b), which indicates their affinity for the dissolved phase. Contaminants with $\log \mathrm{K}_{\text {ow }}$ in this range will not readily adsorb to sediments in the aquifer or other filtering materials in the transport process. Atrazine concentrations were lower in finishedwater samples than in the source-water samples, although the concentration trends were similar (fig. 9). For the six sampling dates when groundwater was the only source water used (no blending with surface water; all groundwater samples except June 9, 2010), groundwater and finished-water concentrations of atrazine were similar (fig. 9). The samples collected for this study were not designed to assess the efficacy of the water treatment for removing herbicides, but demonstrate the potential for certain herbicides to persist throughout the treatment process.

Upstream wastewater discharges contributed a fairly small percentage of the flow to the Big Sioux River near Sioux Falls (usually less than 3 percent during the summer months), but several AOCs associated with wastewater were frequently detected. The large distance between major wastewater discharges and the sampling sites (Watertown and Brookings are about 176 and 76 river miles upstream from Sioux Falls, respectively) allows for substantial removal of these compounds by degradation and settling of particulate-bound contaminants, but bed sediments in the Big Sioux River also can be a source of AOCs (Sando and others, 2006). Carbamazapine (pharmaceutical) and sulfamethoxazole (antibiotic) were detected in more than one-half of the Big Sioux River samples but were detected at lower frequencies in groundwater and not detected in finished water (table 3). Three sterol compounds usually associated with wastewater discharges or manure runoff (cholesterol, beta-sitosterol, and 3-beta-coprostanol) had greater detection frequencies in the Big Sioux River samples (100, 57, and 13 percent, respectively) than in groundwater samples $(14,14$, and 0 percent, respectively) and finished-water samples $(9,0$, and 0 percent, respectively; table 3 and appendix 4). Beta-sitosterol (a plant sterol) also occurs in natural waters and sediments through the breakdown of native vegetation, and can be associated with nonpoint runoff as well as wastewater discharges. The compound 3-betacoprostanol is a carnivore fecal sterol. The direct pathway to surface water explains the frequent occurrence of these 
compounds in the Big Sioux River compared to groundwater and subsequently finished water. In addition, these compounds have $\log \mathrm{K}_{\mathrm{ow}}$ values greater than 8.0 (U.S. Environmental Protection Agency, 2011b), and are more susceptible to natural filtering in groundwater movement. Tributyl phosphate, a manufacturing additive and flame retardant, typically is associated with wastewater effluents and was detected at similar frequencies for the Big Sioux River, groundwater, and finished-water samples $(29,29$, and 33 percent, respectively). The $\log \mathrm{K}_{\mathrm{ow}}$ for tributyl phosphate is less than 5 (Hansch and others, 1995), which may help explain the similar occurrence at all three sites. Sorption to aquifer materials is just one removal mechanism, and other environmental processes (such as volatilization or biological degradation) also will have a substantial effect on the fate and transport of organic compounds.

The measurements of isotopic ratios provide qualitative information regarding the nitrogen sources in the water supply (Cravotta, 2002), because the proportions of multiple nitrogen sources could not be sufficiently estimated using a single sampling location at the terminal point of the source water. The literature-reported range for $\delta^{15} \mathrm{~N}$ values indicative of fertilizers and inorganic sources is about $-3-2 \%$, values for organic sources such as manure and wastewater range from about $10-20 \%$, and values for a combination of the two sources or for soil organic matter are in the intermediate range of 2-10\%o (fig. 6; Clark and Fritz, 1997; Katz and Böhlke, 2000; Tihansky and Sacks, 1997). Most (82 percent) of the $\delta^{15} \mathrm{~N}$ values in the source-water samples were greater than $10 \%$, indicating biological sources as the predominant component of nitrogen in the nitrate of the source water (fig. 6). Three samples of the Big Sioux River had $\delta^{15} \mathrm{~N}$ values between 7-10\%o, indicating a greater proportion of soil organic material or inorganic sources. The varying isotopic composition of nitrogen and oxygen in nitrate in groundwater samples (fig. 7) is not only an effect of changing hydrologic conditions and seasonality, but also could be explained by the blending of groundwater from wells and collection galleries in several aquifers (fig. 4). For example, groundwater from a collection gallery near the Big Sioux River would likely have a much different isotopic signature than a well farther away from surface-water influence.

Source water sampled for this study was a mix of various water supplies within the Big Sioux River Basin that have undergone numerous chemical and biological transformations before reaching the sampling location. These processes (including volatilization, hydrolysis, assimilation, mineralization, nitrification, and denitrification) affect the isotopic signatures of nitrogen and oxygen in nitrate. Volatilization of urea or ammonia nitrogen, the typical form of nitrogen fertilizer in most agricultural areas, leaves the soil relatively enriched in ${ }^{15} \mathrm{~N}$ (Böhlke, 2002). Nitrogen transformations in the soil further fractionate the isotopes of nitrogen and oxygen compounds and obscure the source signatures (Böhlke, 2003). Nitrification is the transformation of organic nitrogen, from manure or wastewater effluent, into nitrite and subsequently nitrate in an aerobic environment. Nitrogen that enters the aquatic environment in the form of nitrate (such as fertilizers) can denitrify into nitrite, nitric oxide, nitrous oxide, and eventually nitrogen gas $\left(\mathrm{N}_{2}\right)$ in an anaerobic environment. The denitrification process preferentially uses the lower $\delta^{15} \mathrm{~N}$ nitrate (from fertilizers), enriching the higher $\delta^{15} \mathrm{~N}$ nitrate (from wastewater and manure) in the remaining nitrate. Previous studies (McMahon and Böhlke, 2006; Böhlke, 2003) used a dissolved oxygen concentration of $2 \mathrm{mg} / \mathrm{L}$ as the maximum concentration for denitrification to occur. Dissolved oxygen concentrations in the Big Sioux River and groundwater samples were between 5 and $13 \mathrm{mg} / \mathrm{L}$, thus denitrification was not likely, but cannot be adequately assessed without knowledge of oxic conditions throughout the basin. Denitrification could be quantified with analysis of dissolved gases (such as $\mathrm{N}_{2}$ ) in the saturated zone (Böhlke, 2002), but dissolved gases were not sampled in this study.

Using the assumption that denitrification was not substantial, fertilizers and other inorganic sources probably are not the dominant source of nitrate in the source water because none of the $\delta^{15} \mathrm{~N}$ values from either surface water or groundwater was less than $7 \%$. Samples with high concentrations of dissolved oxygen, absence of $\mathrm{N}_{2}$ gas, and constant values of $\delta^{18} \mathrm{O}$ are most likely to have $\delta^{15} \mathrm{~N}$ values that reflect the actual nitrogen source characteristics (Böhlke, 2003). Values of $\delta^{18} \mathrm{O}$ were not constant for varying values of $\delta^{15} \mathrm{~N}$ (fig. 7), so various transformation processes likely caused an enrichment of ${ }^{15} \mathrm{~N}$ in the source water. The interpretation of all potential sources of nitrogen cannot be accomplished by use of nitrogen and oxygen isotopes in nitrate alone, but provides a qualitative indication that very little nitrate originates from excess fertilizer runoff, and most nitrate originates from municipal wastewater effluent, manure runoff (either from field application or feeding operations), or fertilizers mineralized by processes in the soil.

\section{Summary and Conclusions}

Anthropogenic organic compounds (AOCs) in drinkingwater sources commonly are derived from municipal, agricultural, and industrial wastewater sources, and are a concern for water-supply managers. Although some of the most commonly used and toxic AOCs are regulated, most are unregulated and human-health effects from many AOCs are uncertain. The city of Sioux Falls, S. Dak., identified a need to investigate potential contaminant origins, including AOCs, when peak nitrate concentrations occur in source water. A cooperative study between the city of Sioux Falls and the U.S. Geological Survey (USGS) was initiated in 2009 to (1) characterize the occurrence of anthropogenic organic compounds in source waters (groundwater and surface water) to water supplies in the Sioux Falls area, (2) determine if the compounds found in the source waters also are present in the finished water, and (3) identify probable sources of nitrate in the Big Sioux River Basin and determine if sources change seasonally or 
under different hydrologic conditions. This report presents analytical results of water-quality samples collected from source water (groundwater blended from multiple wells and collection galleries and surface water from the Big Sioux River) and finished water in the Sioux Falls area. Samples for analyses of AOCs and nutrients were collected on 11 days between June 2009 and August 2010. The 2009-10 period represented two extremes in terms of the prevailing hydrologic conditions. Water year 2009 (October 1, 2008, to September 30, 2009) was the driest year of the decade for the Sioux Falls area, whereas water year 2010 had the most precipitation (43.1 inches) in the 120-year period of record.

Extensive agricultural activities occur in the Big Sioux River Basin, and the largest cities in the basin have developed along the Big Sioux River, contributing urban runoff and wastewater effluent discharges to the river. Outwash deposits along the Big Sioux River and its tributaries underlie much of the Big Sioux River Basin, composing the glacial aquifers that serve as the primary source to water supplies in the Sioux Falls area. These aquifers have areas where they are hydraulically connected to the Big Sioux River, and can be sensitive to infiltration of surface contaminants. The city of Sioux Falls currently (2011) uses groundwater as its primary water source year-round, and supplements the supply with surface water from the Big Sioux River only during periods of increased demand (typically in the summer months).

The study approach included the collection of source- and finished-water samples for the analyses of AOCs, nutrients, and nitrogen and oxygen isotopes in nitrate. Two source-water sites and one finished-water site were sampled during this study. The two source-water sites were the Big Sioux River at an intake location and blended groundwater from multiple wells and collection galleries. Finished water was collected from a flowing water line following water treatment but prior to distribution. Water-quality constituents monitored in this study were chosen to represent a variety of the contaminants known or suspected to occur within the Big Sioux River Basin, including pesticides, pharmaceuticals, sterol compounds, household and industrial products, polycyclic aromatic hydrocarbons, antibiotics, and hormones. A total of 184 AOCs were monitored, of which 40 compounds had relevant U.S. Environmental Protection Agency Maximum Contaminant Levels (MCLs) or USGS Health-Based Screening Levels (HBSLs). The nutrients nitrate, nitrite, ammonia, and orthophosphorus, along with the ratios of the stable isotopes of nitrogen and oxygen in nitrate $\left(\delta^{15} \mathrm{~N}\right.$ and $\left.\delta^{18} \mathrm{O}\right)$, also were analyzed to assess the types of contaminants present in the water supplies in the Sioux Falls area.

Of the 184 AOCs analyzed, 45 compounds (24 percent) were detected in at least one sample of source or finished water, and 13 compounds were detected in at least 20 percent of all samples. Concentrations of detected AOCs were all less than 1 microgram per liter $(\mu \mathrm{g} / \mathrm{L})$, except for concentrations of cholesterol and beta-sitosterol in the Big Sioux River and one detection of bis-(2-ethylhexyl) phthalate in finished water. Concentrations of AOCs were less than $0.1 \mu \mathrm{g} / \mathrm{L}$ in more than 75 percent of the detections. Five compounds (atrazine, cholesterol, deethylatrazine, metolachlor, and prometon) were detected in every sample of source water from the Big Sioux River. The same four herbicides or degradates detected in all Big Sioux River samples also were detected in all groundwater samples. The disinfection byproduct bromoform was detected in every sample of finished water, along with the herbicides atrazine and prometon. Nutrient concentrations varied seasonally in the Big Sioux River and groundwater. In the Big Sioux River, nitrite plus nitrate concentrations typically were less than 1 milligram per liter as nitrogen $(\mathrm{mg} / \mathrm{L}$ as $\mathrm{N})$ for the summer months in 2009, increased to nearly $3 \mathrm{mg} / \mathrm{L}$ as N by January 2010, and reached a maximum of $4.06 \mathrm{mg} / \mathrm{L}$ as N following a June 2010 runoff event. For groundwater samples, nitrite plus nitrate concentrations increased from $0.13 \mathrm{mg} / \mathrm{L}$ as $\mathrm{N}$ in November 2009 to $0.70 \mathrm{mg} / \mathrm{L}$ as $\mathrm{N}$ in March 2010, and then decreased to less than $0.10 \mathrm{mg} / \mathrm{L}$ as $\mathrm{N}$ in the summer months of 2010.

Eight of the AOCs detected have a human-health benchmark (MCL or HBSL) that could be used to evaluate the concentrations in a human-health context. Four compounds had maximum concentrations within an order of magnitude of the benchmark, indicating that additional monitoring of the compound may be warranted. Three herbicides (atrazine, metolachlor, and prometon) and one degradate (deethylatrazine) were detected in finished-water samples as frequently as in source-water samples. The concentrations of herbicides in source water can vary by an order of magnitude from the period of peak application (early summer) to the winter months. Atrazine, metolachlor, and prometon can be highly mobile in sandy soils and aquifers. These herbicides (along with acetochlor) have log octanol-water partitioning coefficients $\left(\log \mathrm{K}_{\mathrm{ow}}\right)$ less than 5 , which indicates their affinity for the dissolved phase. Contaminants with $\log \mathrm{K}_{\mathrm{ow}}$ in this range will not readily adsorb to sediments in the aquifer or other filtering materials in the transport process. Groundwater and finished-water concentrations of atrazine were similar for the six sampling dates when groundwater was the only source water used. Upstream wastewater discharges contributed a fairly small percentage of the flow to the Big Sioux River near Sioux Falls, but several AOCs associated with wastewater were frequently detected. The direct pathway to surface water explains the frequent occurrence of carbamazapine, sulfamethoxazole, cholesterol, beta-sitosterol, and 3-betacoprostanol in the Big Sioux River compared to groundwater and subsequently finished water. In addition, three of these compounds have $\log \mathrm{K}_{\mathrm{ow}}$ values greater than 8.0 and are more susceptible to natural filtering in groundwater movement.

Most (82 percent) of the $\delta^{15} \mathrm{~N}$ values in the source-water samples were greater than 10 per mil, and none of the $\delta^{15} \mathrm{~N}$ values from either surface water or groundwater was less than 7 per mil, indicating biological sources as the predominant component of nitrogen in the nitrate of the source water. The varying isotopic composition of nitrogen and oxygen in nitrate in groundwater samples is not only an effect of 
changing hydrologic conditions and seasonality, but also could be explained by the blending of groundwater from wells and collection galleries producing from several aquifers. Sourcewater samples were a mix of various water supplies within the Big Sioux River Basin that have undergone numerous chemical and biological transformations before reaching the sampling location, and varying $\delta^{18} \mathrm{O}$ values support the conclusion that these processes likely caused an enrichment of ${ }^{15} \mathrm{~N}$ in the source water. The interpretation of all potential sources of nitrogen cannot be accomplished by use of nitrogen and oxygen isotopes in nitrate alone, but provides a qualitative indication that very little nitrate originates from excess fertilizer runoff, and most nitrate originates from municipal wastewater effluent, manure runoff (either from field application or feeding operations), or fertilizers mineralized by processes in the soil.

\section{References Cited}

American Public Health Association, 2005, Standard methods for the examination of water and wastewater (21st ed.): Washington, D.C., American Public Health Association, American Water Works Association, and Water Environment Federation, p. 4-3 to 4-5.

Antignac, J.P., Le Bizec, B., Monteau, F., and Andre, F., 2003, Validation of analytical methods based on mass spectrometric detection according to the "2002/657/EC" European decision-Guideline and application: Analytica Chimica Acta, v. 483, no. 1-2, p. 325-334.

Böhlke, J.K., 2002, Groundwater recharge and agricultural contamination: Hydrogeology Journal, v. 10, p. 153-179.

Böhlke, J.K., 2003, Sources, transport, and reaction of nitrate, in Lindsey, B.D., Phillips, S.W., Donnelly, C.A., Speiran, G.K., Plummer, L.N., Böhlke, J.K., Focazio, M.J., Burton, W.C., and Busenberg, Eurybiades, eds., Residence times and nitrate transport in ground water discharging to streams in the Chesapeake Bay watershed: U.S. Geological Survey Water-Resources Investigations Report 03-4035, p. 25-39.

Childress, C.J.O., Foreman, W.T., Connor, B.F., and Maloney, T.J., 1999, New reporting procedures based on longterm method detection levels and some considerations for interpretations of water-quality data provided by the U.S. Geological Survey National Water Quality Laboratory: U.S. Geological Survey Open-File Report 99-193, 19 p.

City of Sioux Falls, 2011, Water purification, accessed January 12, 2011, at http://www.siouxfalls.org/PublicWorks/ purification.

Christensen, V.G., and Ziegler, A.C., 1998, Atrazine in source water intended for artificial ground-water recharge, southcentral Kansas: U.S. Geological Survey Fact Sheet 074-98, $4 \mathrm{p}$.
Clark, I.D., and Fritz, Peter, 1997, Environmental isotopes in hydrogeology: Boca Raton, Fla., CRC Press/Lewis Publishers, $328 \mathrm{p}$.

Cravotta, C.A., III, 2002, Use of stable isotopes of carbon, nitrogen, and sulfur to identify sources of nitrogen in surface waters in the lower Susquehanna River Basin, Pennsylvania: U.S. Geological Survey Water-Supply Paper 2497, $99 \mathrm{p}$.

Fishman, M.J., ed., 1993, Methods of analysis by the U.S. Geological Survey National Water Quality Laboratory-Determination of inorganic and organic constituents in water and fluvial sediments: U.S. Geological Survey Open-File Report 93-125, 217 p.

Focazio, M.J., Kolpin, D.W., Barnes, K.K., Furlong, E.T., Meyer, M.T., Zaugg, S.D., Barber, L.B., and Thurman, M.E., 2008, A national reconnaissance for pharmaceuticals and other organic wastewater contaminants in the United States-II. Untreated drinking water sources: Science of the Total Environment, v. 402, no. 2-3, p. 201-216.

Foreman, W.T., ReVello, R.C., and Gray, J.L., 2010, Deuterium exchange complicates isotope dilution methods for steroid hormones: SETAC North America 31st Annual Meeting, November 7-11, 2010, Portland, Oreg., abstract no. 670 .

Furlong, E.T., Werner, S.L., Anderson, B.D., and Cahill, J.D., 2008, Determination of human-health pharmaceuticals in filtered water by chemically modified styrene-divinylbenzene resin-based solid-phase extraction and highperformance liquid chromatography/mass spectrometry: U.S. Geological Survey Techniques and Methods, book 5, chap. B5, 56 p.

Gilliom, R.J., Barbash, J.E., Crawford, C.G., Hamilton, P.A., Martin, J.D., Nakagaki, Naomi, Nowell, L.H., Scott, J.C., Stackelberg, P.E., Thelin, G.P., and Wolock, D.M., 2006, The quality of our Nation's waters-Pesticides in the Nation's streams and ground water, 1992-2001: U.S. Geological Survey Circular 1291, 173 p.

Hansch, Corwin, Leo, Albert, and Hoekman, David, 1995, Exploring QSAR - Volume 2- Hydrophobic, electronic and steric constants: Washington, D.C., American Chemical Society, $348 \mathrm{p}$.

Hollocher, T.C., 1984, Source of oxygen atoms in nitrate in the oxidation of nitrite by Nitrobacter agilis and evidence against a P-O-N anhydrite mechanism in oxidative phosphorylation: Archives of Biochemistry and Biophysics, v. 233, no. 2, p. 721-727.

Homer, C., Huang, C., Yang, L., Wylie, B., and Coan, M., 2004, Development of a 2001 National Landcover Database for the United States: Photogrammetric Engineering and Remote Sensing, v. 70 , no. 7, p. 829-840. 
Katz, B.G., and Böhlke, J.K., 2000, Monthly variability and possible sources of nitrate in ground water beneath mixed agricultural land use, Suwannee and Lafayette Counties, Florida: U.S. Geological Survey Water-Resources Investigations Report 2000-4219, 28 p.

Kingsbury, J.A., Delzer, G.C., and Hopple, J.A., 2008, Anthropogenic organic compounds in source water of nine community water systems that withdraw from streams, 2002-05: U.S. Geological Survey Scientific Investigations Report 2008-5208, 68 p.

Lawrence, S.J., and Sando, S.K., 1991, Quality of water from surficial-outwash aquifers in the Big Sioux River Basin, eastern South Dakota: U.S. Geological Survey WaterResources Investigations Report 89-4170, 81 p.

Lindgren, R.J., and Niehus, C.A., 1992, Water resources of Minnehaha County, South Dakota: U.S. Geological Survey Water-Resources Investigations Report 91-4101, 80 p.

Madsen, J.F., Sandstrom, M.W., and Zaugg, S.D., 2002, Methods of analysis by the U.S. Geological Survey National Water Quality Laboratory-A method supplement for the determination of fipronil and degradates in water by gas chromatography/mass spectrometry: U.S. Geological Survey Open-File Report 2002-462, 11 p.

Martin, J.D., 2002, Variability of pesticide detections and concentrations in field replicate water samples collected for the National Water-Quality Assessment Program, 1992-97: U.S. Geological Survey Water-Resources Investigations Report 2001-4178, 84 p.

Martin, J.E., Sawyer, J.F., Fahrenbach, M.D., Tomhave, D.W., and Schulz, L.D., 2004, Geologic map of South Dakota: South Dakota Geological Survey, General Map 10, scale 1:500,000.

McMahon, P.B., and Böhlke, J.K., 2006, Regional patterns in the isotopic composition of natural and anthropogenic nitrate in groundwater, High Plains, U.S.A.: Environmental Science and Technology, v. 40, p. 2,965-2,970.

Meyer, M.T., Lee, E.A., Ferrell, G.M., Bumgarner, J.E., and Varnes, Jerry, 2007, Evaluation of offline tandem and online solid-phase extraction with liquid chromatography/electrospray ionization-mass spectrometry for analysis of antibiotics in ambient water and comparison to an independent method: U.S. Geological Survey Scientific Investigations Report 2007-5021, 28 p.

National Oceanic and Atmospheric Administration, 2000-10, Annual climatological summary, Sioux Falls Foss Field: National Oceanic and Atmospheric Administration, National Climatic Data Center, accessed December 8, 2010, at http:// www4.ncdc.noaa.gov/cgi-win/wwcgi.dll?wwDI StnSrch $\sim S t$ $n I D \sim 20017674$.
Révész, Kinga, and Casciotti, Karen, 2007, Determination of the $\delta(15 \mathrm{~N} / 14 \mathrm{~N})$ and $\delta(18 \mathrm{O} / 16 \mathrm{O})$ nitrate in water, RSIL Lab Code 2900: U.S. Geological Survey Techniques and Methods, book 10, chap. C17, 24 p.

Sando, S.K., Furlong, E.T., Gray, J.L., Meyer, M.T., and Bartholomay, R.C., 2005, Occurrence of organic wastewater compounds in wastewater effluent and the Big Sioux River in the upper Big Sioux River Basin, South Dakota, 2003-2004: U.S. Geological Survey Scientific Investigations Report 2005-5249, 108 p.

Sando, S.K., Furlong, E.T., Gray, J.L., and Meyer, M.T., 2006, Occurrence of organic wastewater compounds in drinking water, wastewater effluent, and the Big Sioux River in or near Sioux Falls, South Dakota, 2001-2004: U.S. Geological Survey Scientific Investigations Report 2006-5118, $178 \mathrm{p}$.

Sandstrom, M.W., and Delzer, G.C., 2007, Field methodsDechlorination reagent for organic compounds tested resulting in new preservative requirements for water samples containing residual chlorine: U.S. Geological Survey Office of Water Quality Water-Quality Information Note 2007.04, 2 p., accessed July 29, 2011, at http://water.usgs.gov/usgs/ owq/WaQI/WaQI07.04.pdf.

Sandstrom, M.W., Stroppel, M.E., Foreman, W.T., and Schroeder, M.P., 2001, Methods of analysis by the U.S. Geological Survey National Water Quality Laboratory-Determination of moderate-use pesticides and selected degradates in water by C-18 solid-phase extraction and gas chromatography/mass spectrometry: U.S. Geological Survey WaterResources Investigations Report 2001-4098, 70 p.

Tihansky, A.B., and Sacks, L.A., 1997, Evaluation of nitrate sources using nitrogen-isotope techniques in shallow ground water within selected lake basins in the Central Lakes District, Polk and Highlands Counties, Florida: U.S. Geological Survey Water-Resources Investigations Report 97-4207, $28 \mathrm{p}$.

Timme, P.J., 1995, National Water Quality Laboratory, 1995 services catalog: U.S. Geological Survey Open-File Report 95-352, p. 92.

Toccalino, P.L., 2007, Development and application of HealthBased Screening Levels for use in water-quality assessments: U.S. Geological Survey Scientific Investigations Report 2007-5106, 12 p.

Toccalino, P.L., Norman, J.E., Booth, N.L., and Zogorski, J.S., 2008, Health-Based Screening Levels-A tool for evaluating what water-quality data may mean to human health: U.S. Geological Survey National Water-Quality Assessment Program, accessed January 5, 2011, at http://water.usgs.gov/ nawqa/HBSL/. 
U.S. Census Bureau, 2011, Population finder, accessed January 4, 2011, at http://www.census.gov/.

U.S. Department of Agriculture, 2012, National Agriculture Statistics Service, accessed May 18, 2012, at http://www. pestmanagement.info/nass/.

U.S. Environmental Protection Agency, 2009, Drinking water contaminants, National primary drinking water regulations: accessed March 20, 2009, at http://www.epa.gov/safewater/ contaminants/index.html.

U.S. Environmental Protection Agency, 2011a, Drinking water analytical methods, accessed June 3, 2011, at http://water. epa.gov/scitech/drinkingwater/labcert/analyticalmethods. cfm.

U.S. Environmental Protection Agency, 2011b, Estimation Programs Interface Suite ${ }^{\mathrm{TM}}$ for Microsoft ${ }^{\circledR}$ Windows, v. 4.10: Washington, D.C.

U.S. Environmental Protection Agency, 2011c, Permit Compliance System, accessed July 26, 2011, at http://www.epa. gov/enviro/facts/pcs/search.html.

U.S. Geological Survey, variously dated, National field manual for the collection of water-quality data: U.S. Geological Survey Techniques of Water-Resources Investigations, book 9, chaps. A1-A9, accessed March 20, 2009, at http:// pubs.water.usgs.gov/twri9A.
U.S. Geological Survey, Reston Stable Isotope Laboratory, 2008, Instructions for collecting samples, accessed July 18 , 2011, at http://isotopes.usgs.gov/lab/instructions.html.

U.S. Geological Survey, 2011, USGS water data for South Dakota, accessed July 13, 2011, at http://waterdata.usgs. $\mathrm{gov} / \mathrm{sd} / \mathrm{nwis} /$.

Valder, J.F., Delzer, G.C., Price, C.V., and Sandstrom, M.W., 2008, Study design and percent recoveries of anthropogenic organic compounds with and without the addition of ascorbic acid to preserve water samples containing free chlorine, 2004-06: U.S. Geological Survey Open-File Report 2008-1226, 85 p., accessed July 18, 2011, at http://pubs. usgs.gov/of/2008/1226/.

Wagner, R.J., Boulger, R.W., Jr., Oblinger, C.J., and Smith, B.A., 2006, Guidelines and standard procedures for continuous water-quality monitors - Station operation, record computation, and data reporting: U.S. Geological Survey Techniques and Methods 1-D3, 51 p. +8 attachments; accessed September 14, 2011, at http://pubs.water.usgs.gov/ tmld3.

Zaugg, S.D., Smith, S.G., and Schroeder, M.P., 2006, Determination of wastewater compounds in whole water by continuous liquid-liquid extraction and capillary-column gas chromatography/mass spectrometry: U.S. Geological Survey Techniques and Methods, book 5, chap. B4, 30 p. 



\section{Appendixes 1-4}


Appendix 1. Reporting levels and relevant benchmarks for anthropogenic organic compounds analyzed.

[USGS, U.S. Geological Survey; CASRN, Chemical Abstracts Service Registry Number; MCL, Maximum Contaminant Level; HBSL, Health-Based Screening Level; $\mu \mathrm{g} / \mathrm{L}$, micrograms per liter; ng/L, nanograms per liter; --, not available]

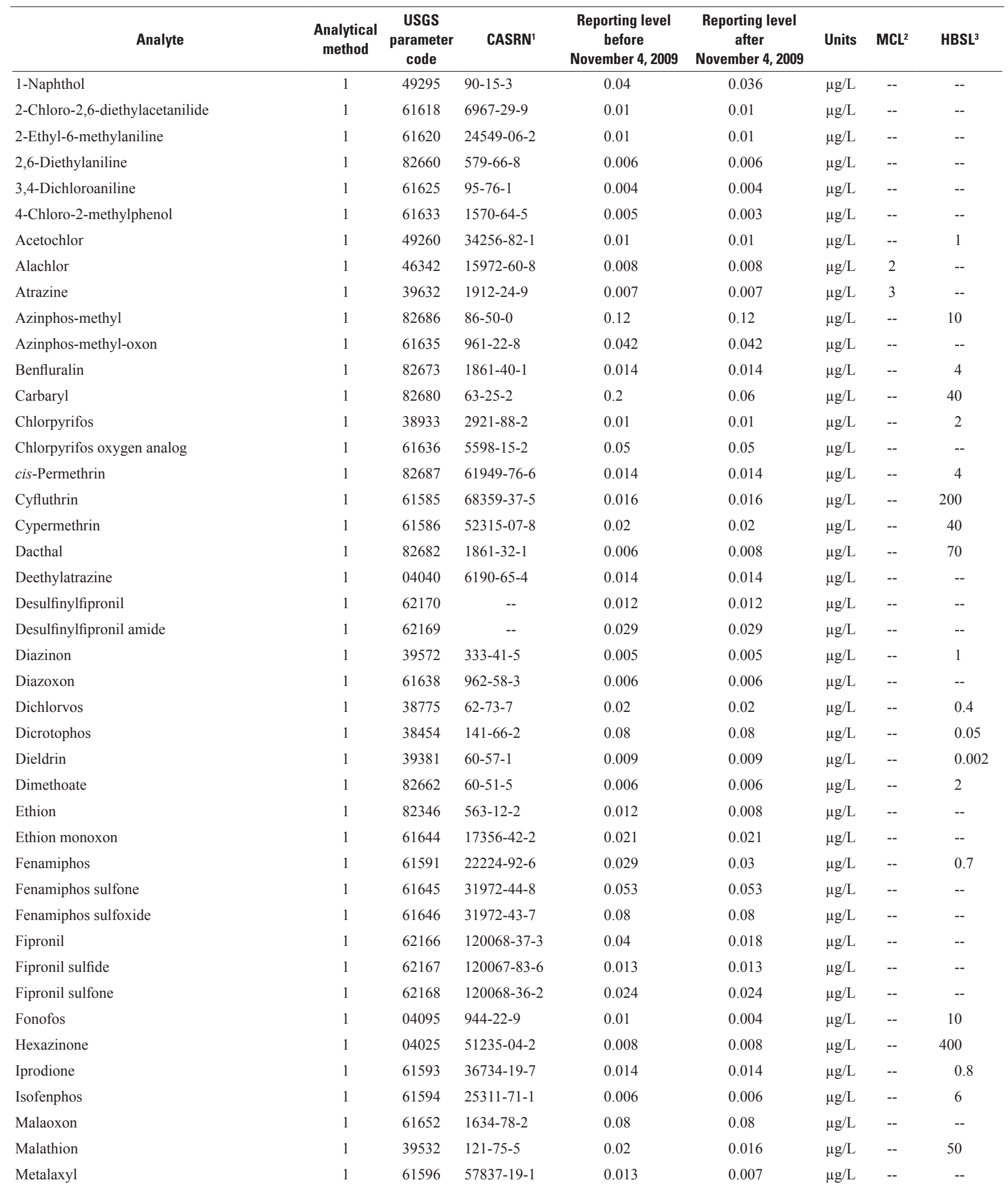


Appendix 1. Reporting levels and relevant benchmarks for anthropogenic organic compounds analyzed.—Continued

[USGS, U.S. Geological Survey; CASRN, Chemical Abstracts Service Registry Number; MCL, Maximum Contaminant Level; HBSL, Health-Based Screening Level; $\mu \mathrm{g} / \mathrm{L}$, micrograms per liter; ng/L, nanograms per liter; --, not available]

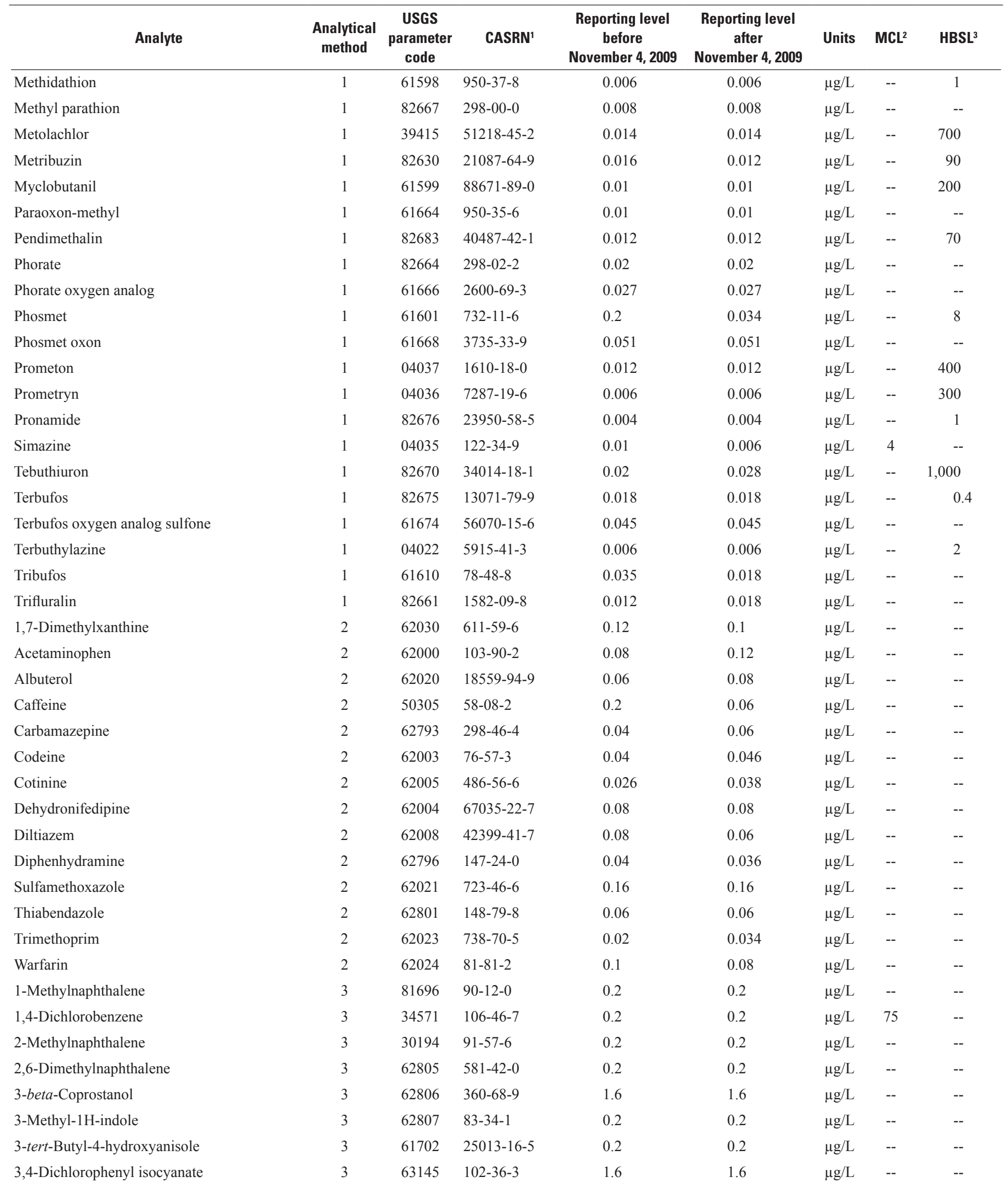


Appendix 1. Reporting levels and relevant benchmarks for anthropogenic organic compounds analyzed.-Continued

[USGS, U.S. Geological Survey; CASRN, Chemical Abstracts Service Registry Number; MCL, Maximum Contaminant Level; HBSL, Health-Based Screening Level; $\mu \mathrm{g} / \mathrm{L}$, micrograms per liter; ng/L, nanograms per liter; --, not available]

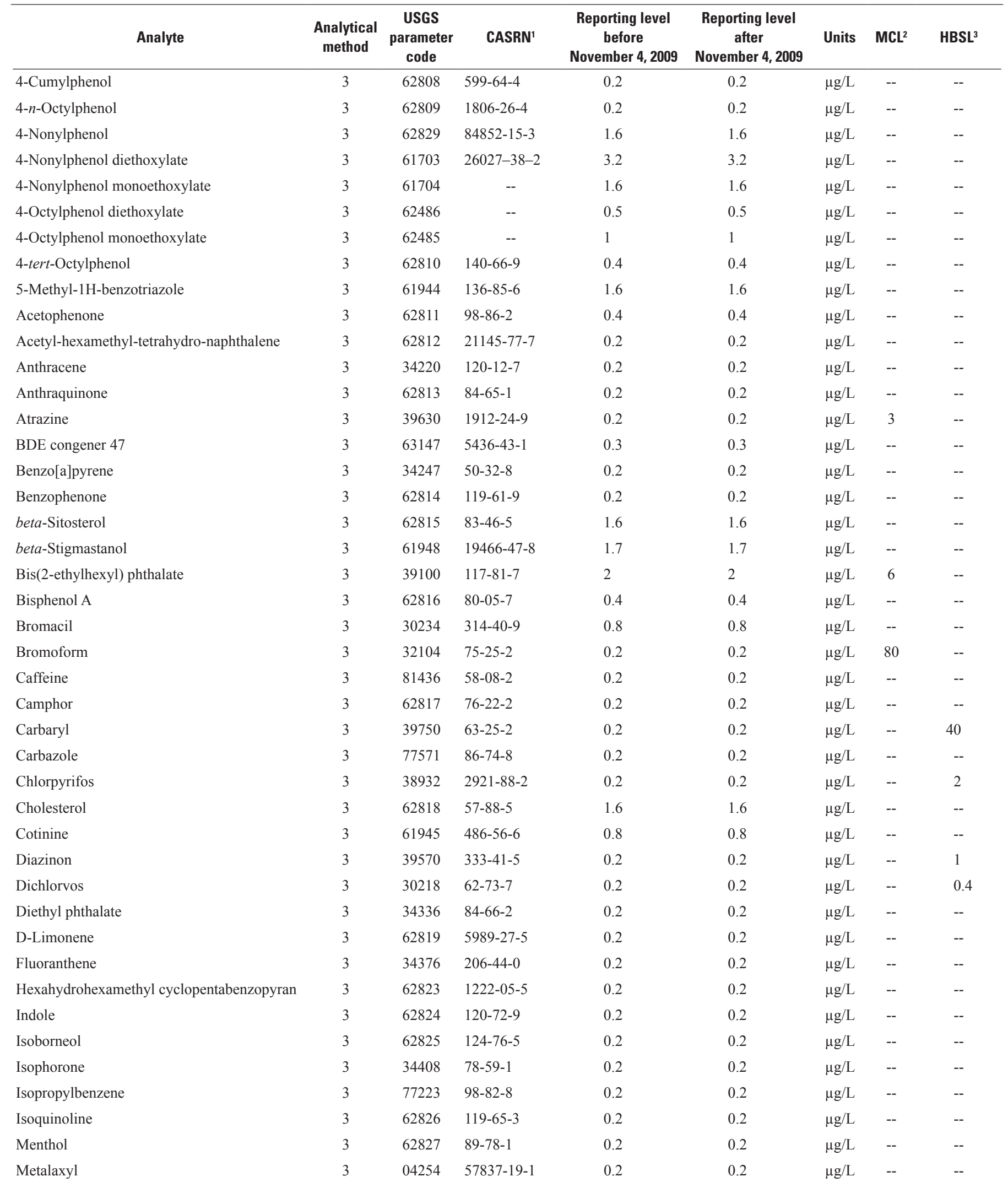


Appendix 1. Reporting levels and relevant benchmarks for anthropogenic organic compounds analyzed.—Continued

[USGS, U.S. Geological Survey; CASRN, Chemical Abstracts Service Registry Number; MCL, Maximum Contaminant Level; HBSL, Health-Based Screening Level; $\mu \mathrm{g} / \mathrm{L}$, micrograms per liter; ng/L, nanograms per liter; --, not available]

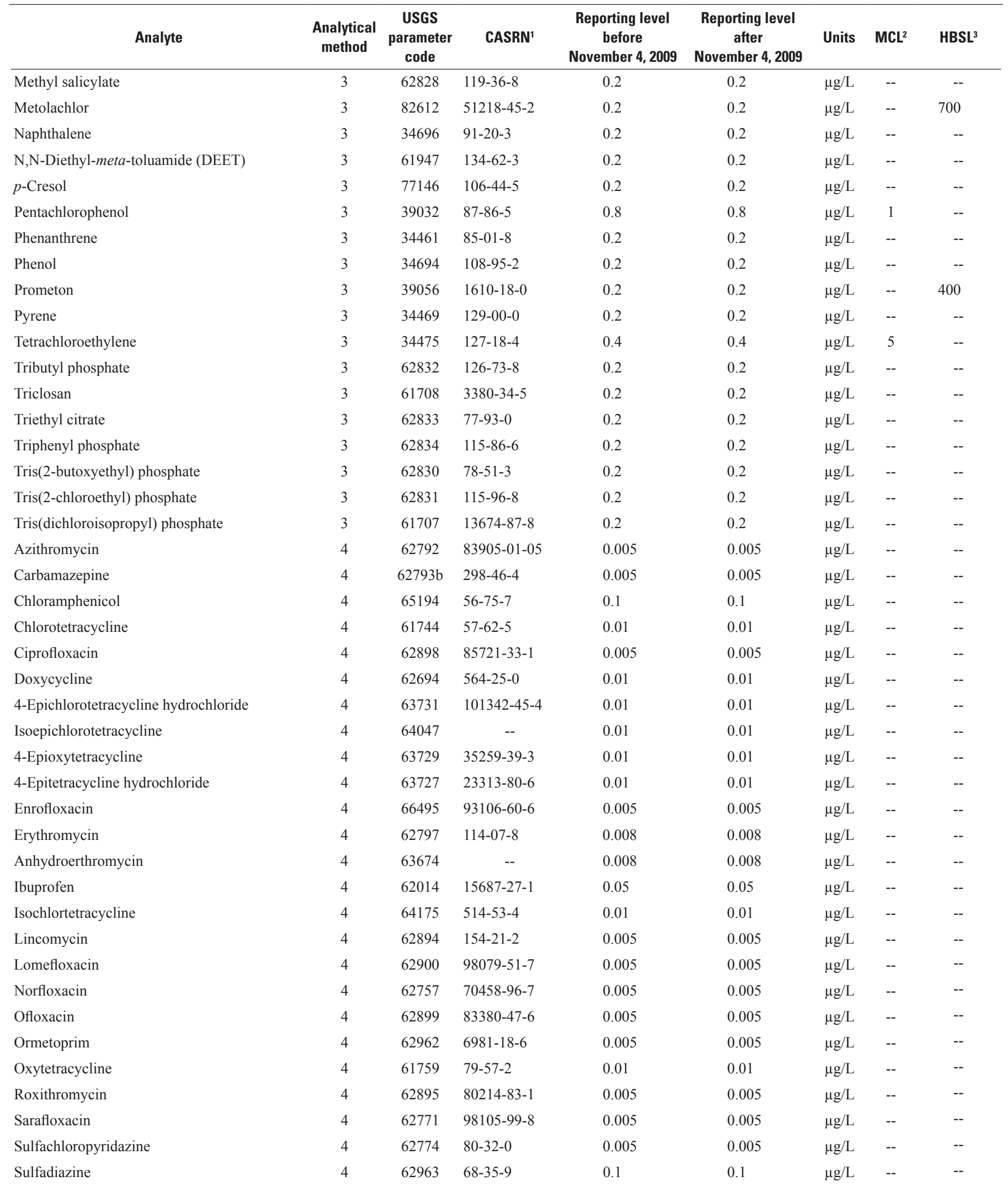


Appendix 1. Reporting levels and relevant benchmarks for anthropogenic organic compounds analyzed.—Continued

[USGS, U.S. Geological Survey; CASRN, Chemical Abstracts Service Registry Number; MCL, Maximum Contaminant Level; HBSL, Health-Based Screening Level; $\mu \mathrm{g} / \mathrm{L}$, micrograms per liter; ng/L, nanograms per liter; --, not available]

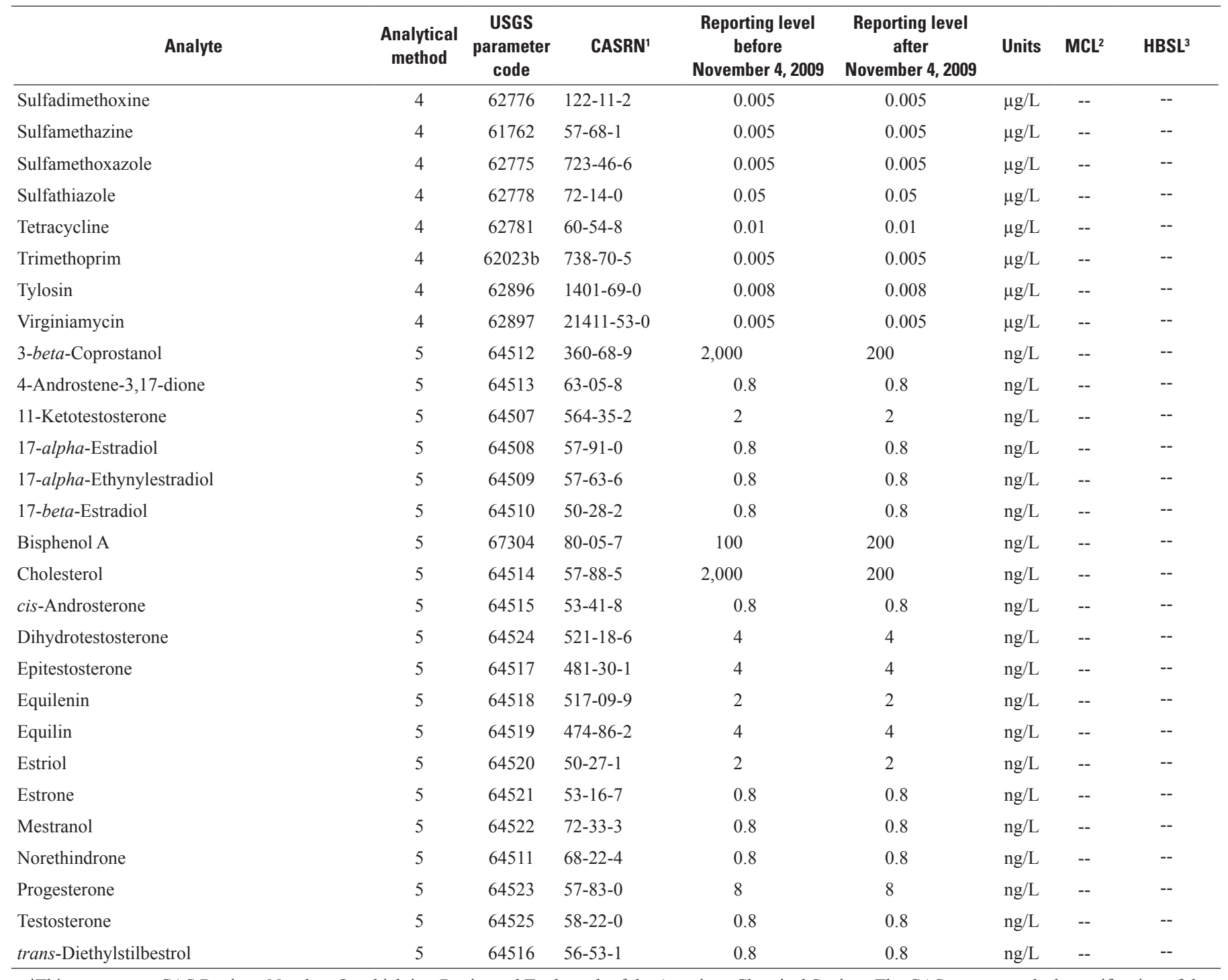

${ }^{1}$ This report uses CAS Registry Numbers ${ }^{\circledR}$, which is a Registered Trademark of the American Chemical Society. The CAS recommends the verification of the CASRNs through CAS Client ServicesSM.

${ }^{2}$ From U.S. Environmental Protection Agency (2009).

${ }^{3}$ From Toccalino and others (2008). 


\section{Appendix 2. Detailed Description of Method for Analysis of Hormones}

A research method (analytical method 5) under development at the U.S. Geological Survey (USGS) National Water Quality Laboratory (NWQL) was used to analyze for 16 steroid hormones plus four other compounds, with an expanded method description provided herein (James Gray, Rhiannon ReVello, and William Foreman, National Water Quality Laboratory, written commun., 2011). Field samples for this method were collected using USGS protocols for organic contaminants, except that the samples were contained in 0.5-liter high-density polyethylene (HDPE) bottles. Samples not processed within 3 days at the NWQL were held frozen at no more than -5 degrees Celsius $\left({ }^{\circ} \mathrm{C}\right)$ until the day preceding extraction when allowed to thaw at room temperature.

At the NWQL, samples were fortified with 50 milligrams of sodium chloride and isotopically labeled compounds that were used as isotope dilution standards (IDSs; see table 5). The sample was poured into a stainless-steel extraction tube fitted with a multigrade glass-fiber filter (GFF) positioned over a reverse phase octyldecyl surface-modified-silica embedded glass-fiber filter disk ( $\mathrm{C}_{18}$ disk). The sample was passed through the combined $\mathrm{GFF} / \mathrm{C}_{18}$ disk under pressure, as needed. Following compound isolation, the $\mathrm{GFF} / \mathrm{C}_{18}$ disk was rinsed with 10 milliliters $(\mathrm{mL})$ of 25-percent methanol in reagent water to remove polar compounds that interfere with gas-chromatography, tandem-quadrupole, mass-spectrometry analysis. Nitrogen gas was passed through the $\mathrm{GFF} / \mathrm{C}_{18}$ disk to remove residual water, and the method compounds were eluted with two $20-\mathrm{mL}$ additions of methanol. The eluent was evaporated to dryness at $25^{\circ} \mathrm{C}$ with nitrogen gas and reconstituted in $2 \mathrm{~mL}$ of a 5 -percent methanol in dichloromethane solution and allowed to sit for at least 30 minutes. The extract was passed through a 1-gram Florisil solid-phase extraction column and eluted with an additional $22 \mathrm{~mL}$ of 5-percent methanol/dichloromethane. The eluent was reduced in volume to about $1 \mathrm{~mL}$ with nitrogen gas, quantitatively transferred to a 5 -mL reaction vial with 5-percent methanol/dichloromethane rinses, and evaporated to dryness. Processing of multi-level calibration standards contained in reaction vials was included beginning at this evaporation step. Ketone and alcohol groups on the analytes and IDSs were derivatized to trimethylsilyl or trimethylsilyl-enol ether analogs to increase compound volatility and minimize compound interactions with active sites in the gas-chromatography system. Derivation was accomplished by adding 200 microliters of $N$-methyl- $N$-(trimethylsilyl)trifluoroacetamide (MSTFA) activated with 2-(trimethylsilyl) ethanethiol and ammonium iodide, and heating the MSTFA solution to $65^{\circ} \mathrm{C}$ for 1 hour. The solution also contains cholestane- $d_{6}$ and chrysene- $d_{12}$ as injection internal standards.

The extract was transferred to a gas-chromatography vial, and the analytes were separated by gas chromatography and detected by tandem quadrupole mass spectrometry using a Quattro-micro-GC (Waters Corp., Milford, Mass.). Compounds were separated by using a 30-meter long by 0.25-millimeter internal diameter Rxi XLB GC column with 0.25-micrometer film thickness (Restek Corp., Bellefonte, $\mathrm{Pa}$.) and a multiple ramp temperature program. Analytes were detected by tandem-quadrupole mass spectrometry by monitoring the product ions of three specific precursor-to-product ion transitions. Positive analyte identification requires the presence of at least two unique transition product ions, with ion ratios not deviating from those in a standard by more than specified tolerances (Antignac and others, 2003).

Six of the original 13 IDS compounds - 4-androstene3,17-dione- $d_{7}$; dihydrotestosterone- $d_{4}$; estrone- $d_{4}$; norethindrone- $d_{6}$; testosterone- $d_{5}$; and progesterone- $d_{9}$-were found to be susceptible to deuterium-hydrogen exchange under nonroutine sample-preparation conditions (water bath temperatures above ambient temperature of $25^{\circ} \mathrm{C}$ ) or prolonged IDS standard storage periods (months) in methanol (Foreman and others, 2010). Loss of deuterium results in an underestimate of the IDS total mass in the sample extract and, thus, an underestimate of IDS absolute recovery, which produces a positive bias in the determined analyte concentration. Consequently, these six deuterium-labeled IDSs were removed from the method and were not used for samples collected after November 4, 2009. Reported concentrations of analytes normally determined using these six IDS were censored to the reporting level or a raised reporting level, if needed, or were quantified relative to 17-alpha-ethynylestradiol- $d_{4}$ to eliminate risk of positive bias in analyte concentration for those samples collected through November 4, 2009, when deuterium loss was evident or suspected.

Samples collected after November 4, 2009, were fortified with the 10 deuterium or carbon- $13\left({ }^{13} \mathrm{C}\right)$ labeled IDSs shown in table 5, five of which were unchanged from those used previously. Replacement IDSs contained either carbon-13 or were non-direct analogs of the analytes that have deuterium labels in positions not adjacent to a ketone group and, thus, are not susceptible to deuterium-loss. In addition, 17-beta-estradiol- ${ }^{13} \mathrm{C}_{6}$ replaced 17-beta-estradiol- $d_{4}$ and 16-epiestriol- $d_{2}$ replaced estriol- $d_{3}$ to further minimize risk of IDS interference with the analyte's parent ion at concentrations near the instrumental detection level of the gas chromatography/tandem mass spectrometry. Six of the 10 IDS compounds were exact isotopic analogs of method analytes. The remaining 14 method analytes also were quantified using isotope dilution by using 1 of the other 4 IDSs that have similar related chemical functionality but are not a direct isotopic analog of the analyte.

All 20 method analytes were quantified relative to a specific IDS compound by using an isotope-dilution quantification procedure that automatically corrects for procedural losses in the reported analyte concentration on the basis of the absolute method recovery of the IDS. For samples collected through November 4, 2009, 13 deuterium-labeled IDS compounds were used that were exact isotopic analogs of method analytes (table 5). The remaining seven method analytes in these samples were quantified relative to one of the IDS compounds that has similar chemical functionality but is not a direct isotopic analog of the analyte (table 5). 
Table 5. Analyte and the corresponding isotope dilution standard (IDS) used for its quantification.

[The six analytes with direct IDS analogs that were susceptible to deuterium loss (D-loss) are shown in bold italics. Four analytes quantified with non-direct IDS analogs susceptible to D-loss are shown in bold. Six IDSs that contain ketone functional groups (keto-IDSs) that can undergo deuterium loss (D-loss) are shown in bold. USGS, U.S. Geological Survey; CASRN, Chemical Abstracts Service Registry Number; ng/L, nanograms per liter]

\begin{tabular}{|c|c|c|c|c|c|c|}
\hline Analyte & $\begin{array}{l}\text { USGS } \\
\text { parameter } \\
\text { code }\end{array}$ & CASRN ${ }^{1}$ & $\begin{array}{c}\text { Reporting level } \\
\text { through } \\
\text { November 4, } 2009\end{array}$ & $\begin{array}{c}\text { Reporting level } \\
\text { after } \\
\text { November 4, } 2009\end{array}$ & $\begin{array}{l}\text { Isotope dilution standard used } \\
\text { for samples collected through } \\
\text { November 4, } 2009\end{array}$ & $\begin{array}{c}\text { Isotope dilution standard used } \\
\text { for samples collected after } \\
\text { November 4, } 2009\end{array}$ \\
\hline 11-ketotestosterone & 64507 & $564-35-2$ & 2 & 2 & testosterone- $d_{5}$ & nandrolone- $16,16,17-d_{3}$ \\
\hline 17-alpha-Estradiol & 64508 & $57-91-0$ & 0.8 & 0.8 & 17-beta-estradiol- $d_{4}$ & 17-beta-estradiol- ${ }^{13} \mathrm{C}_{6}$ \\
\hline 17-alpha-Ethynylestradiol & 64509 & $57-63-6$ & 0.8 & 0.8 & 17-alpha-ethynylestradiol- $d_{4}$ & 17-alpha-ethynylestradiol- $d_{4}$ \\
\hline 17-beta-Estradiol & 64510 & $50-28-2$ & 0.8 & 0.8 & 17-beta-estradiol- $d_{4}$ & 17-beta-estradiol- ${ }^{13} \mathrm{C}_{6}$ \\
\hline norethindrone & 64511 & $68-22-4$ & 0.8 & 0.8 & norethindrone- $d_{6}$ & nandrolone-16,16,17- $d_{3}$ \\
\hline 3-beta-Coprostanol & 64512 & $360-68-9$ & 2,000 & 200 & cholesterol- $d_{7}$ & cholesterol- $d_{7}$ \\
\hline 4-androstene-3,17-dione & 64513 & $63-05-8$ & 0.8 & 0.8 & 4-androstene-3,17-dione- $d_{7}$ & nandrolone-16,16,17- $d_{3}$ \\
\hline cholesterol & 64514 & $57-88-5$ & 2,000 & 200 & cholesterol- $d_{7}$ & cholesterol- $d_{7}$ \\
\hline cis-androsterone & 64515 & $53-41-8$ & 0.8 & 0.8 & dihydrotestosterone- $d_{4}$ & nandrolone- $16,16,17-d_{3}$ \\
\hline trans-Diethylstilbestrol & 64516 & $56-53-1$ & 0.8 & 0.8 & trans-diethylstilbestrol- $d_{8}$ & trans-diethylstilbestrol- $d_{8}$ \\
\hline epitestosterone & 64517 & $481-30-1$ & 4 & 4 & testosterone- $d_{5}$ & nandrolone- $16,16,17-d_{3}$ \\
\hline equilenin & 64518 & $517-09-9$ & 2 & 2 & 17-beta-estradiol- $d_{4}$ & 17-beta-estradiol- ${ }^{13} \mathrm{C}_{6}$ \\
\hline equilin & 64519 & $474-86-2$ & 4 & 4 & estrone- $d_{4}$ & estrone- ${ }^{13} \mathrm{C}_{6}$ \\
\hline estriol & 64520 & $50-27-1$ & 2 & 2 & estriol- $d_{3}$ & 16-epiestriol- $d_{2}$ \\
\hline estrone & 64521 & $53-16-7$ & 0.8 & 0.8 & estrone- $d_{4}$ & estrone $-{ }^{13} \mathrm{C}_{6}$ \\
\hline mestranol & 64522 & $72-33-3$ & 0.8 & 0.8 & mestranol- $d_{4}$ & mestranol- $d_{4}$ \\
\hline progesterone & 64523 & $57-83-0$ & 8 & 8 & progesterone- $d_{9}$ & medroxyprogesterone- $d_{3}$ \\
\hline dihydrotestosterone & 64524 & $521-18-6$ & 4 & 4 & dihydrotestosterone- $d_{4}$ & nandrolone-16,16,17- $d_{3}$ \\
\hline testosterone & 64525 & $58-22-0$ & 0.8 & 0.8 & testosterone- $d_{5}$ & nandrolone- $16,16,17-d_{3}$ \\
\hline bisphenol A & 67304 & $80-05-7$ & 100 & 200 & bisphenol A- $d_{16}$ & bisphenol A- $d_{16}$ \\
\hline
\end{tabular}

${ }^{1}$ This report uses CAS Registry Numbers ${ }^{\circledR}$, which is a Registered Trademark of the American Chemical Society. The CAS recommends the verification of the CASRNs through CAS Client Services ${ }^{\text {SM }}$ 
Appendix 3. Percent recoveries of anthropogenic organic compounds for environmental matrix spike samples.

[USGS, U.S. Geological Survey; --, not available]

\begin{tabular}{|c|c|c|c|c|c|c|c|c|}
\hline \multirow[t]{2}{*}{ Analyte } & \multirow[t]{2}{*}{$\begin{array}{c}\text { Analytical } \\
\text { method }\end{array}$} & \multirow[t]{2}{*}{$\begin{array}{l}\text { USGS } \\
\text { parameter } \\
\text { code }\end{array}$} & $\begin{array}{c}\text { Big Sioux } \\
\text { River (site } \\
\text { 433600096442400) } \\
\end{array}$ & $\begin{array}{c}\text { Finished } \\
\text { water (site } \\
\text { 433419096434200) }\end{array}$ & $\begin{array}{c}\text { Ground- } \\
\text { water (site } \\
\text { 433421096434401) }\end{array}$ & $\begin{array}{c}\text { Finished } \\
\text { water (site } \\
\text { 433419096434200) }\end{array}$ & $\begin{array}{c}\text { Ground- } \\
\text { water (site } \\
\text { 433421096434401) }\end{array}$ & \multirow[t]{2}{*}{ Median } \\
\hline & & & 8/3/2009 & 8/3/2009 & $2 / 17 / 2010$ & $2 / 17 / 2010$ & 7/29/2010 & \\
\hline 1-Naphthol & 1 & 49295 & 18 & 16 & 38 & 45 & 92 & 38 \\
\hline 2-Chloro-2,6-diethylacetanilide & 1 & 61618 & 128 & 120 & 112 & 107 & 137 & 120 \\
\hline 2-Ethyl-6-methylaniline & 1 & 61620 & 94 & 83 & 77 & 79 & 97 & 83 \\
\hline 2,6-Diethylaniline & 1 & 82660 & 99 & 94 & 85 & 85 & 108 & 94 \\
\hline 3,4-Dichloroaniline & 1 & 61625 & 73 & 52 & 74 & 73 & 90 & 73 \\
\hline 4-Chloro-2-methylphenol & 1 & 61633 & 72 & 76 & 49 & 66 & 86 & 72 \\
\hline Acetochlor & 1 & 49260 & 122 & 112 & 122 & 115 & 155 & 122 \\
\hline Alachlor & 1 & 46342 & 119 & 110 & 121 & 115 & 138 & 119 \\
\hline Atrazine & 1 & 39632 & 121 & 100 & 107 & 101 & 121 & 107 \\
\hline Azinphos-methyl & 1 & 82686 & 158 & 139 & 136 & 130 & 235 & 139 \\
\hline Azinphos-methyl-oxon & 1 & 61635 & 58 & 53 & 125 & 87 & 115 & 87 \\
\hline Benfluralin & 1 & 82673 & 72 & 75 & 83 & 89 & 87 & 83 \\
\hline Carbamazepine & 1 & 82687 & 88 & 113 & 79 & 86 & 141 & 88 \\
\hline Carbaryl & 1 & 82680 & 136 & 137 & 121 & 124 & 141 & 136 \\
\hline Chlorpyrifos & 1 & 38933 & 123 & 133 & 63 & 107 & 96 & 107 \\
\hline Chlorpyrifos oxygen analog & 1 & 61636 & 0 & 28 & 23 & 108 & 64 & 28 \\
\hline Cyfluthrin & 1 & 61585 & 116 & 135 & 82 & 117 & 117 & 117 \\
\hline Cypermethrin & 1 & 61586 & 110 & 120 & 81 & 106 & 116 & 110 \\
\hline Dacthal & 1 & 82682 & 120 & 112 & 116 & 112 & 119 & 116 \\
\hline Deethylatrazine & 1 & 04040 & 71 & 58 & 83 & 82 & 139 & 82 \\
\hline Desulfinylfipronil & 1 & 62170 & 105 & 96 & 118 & 113 & 159 & 113 \\
\hline Desulfinylfipronil amide & 1 & 62169 & 110 & 109 & 124 & 136 & 105 & 110 \\
\hline Diazinon & 1 & 39572 & 112 & 109 & 98 & 100 & 117 & 109 \\
\hline Diazoxon & 1 & 61638 & 65 & 91 & 120 & 132 & 145 & 120 \\
\hline Dichlorvos & 1 & 38775 & 5 & 38 & 8 & 78 & 47 & 38 \\
\hline Dicrotophos & 1 & 38454 & 38 & 47 & 19 & 51 & 64 & 47 \\
\hline Dieldrin & 1 & 39381 & 83 & 84 & 89 & 89 & 64 & 84 \\
\hline Dimethoate & 1 & 82662 & 51 & 43 & 69 & 69 & 84 & 69 \\
\hline Ethion & 1 & 82346 & 114 & 106 & 96 & 101 & 98 & 101 \\
\hline
\end{tabular}




\begin{tabular}{|c|c|c|c|c|c|c|c|c|}
\hline \multirow[t]{2}{*}{ Analyte } & \multirow[t]{2}{*}{$\begin{array}{l}\text { Analytical } \\
\text { method }\end{array}$} & \multirow{2}{*}{$\begin{array}{c}\text { USGS } \\
\text { parameter } \\
\text { code }\end{array}$} & $\begin{array}{c}\text { Big Sioux } \\
\text { River (site } \\
\text { 433600096442400) }\end{array}$ & $\begin{array}{c}\text { Finished } \\
\text { water (site } \\
\text { 433419096434200) }\end{array}$ & $\begin{array}{c}\text { Ground- } \\
\text { water (site } \\
\text { 433421096434401) }\end{array}$ & $\begin{array}{c}\text { Finished } \\
\text { water (site } \\
\text { 433419096434200) }\end{array}$ & $\begin{array}{c}\text { Ground- } \\
\text { water (site } \\
\text { 433421096434401) }\end{array}$ & \multirow[t]{2}{*}{ Median } \\
\hline & & & $8 / 3 / 2009$ & $8 / 3 / 2009$ & $2 / 17 / 2010$ & 2/17/2010 & 7/29/2010 & \\
\hline Ethion monoxon & 1 & 61644 & 97 & 108 & 118 & 127 & 102 & 108 \\
\hline Fenamiphos & 1 & 61591 & 93 & 98 & 116 & 129 & 67 & 98 \\
\hline Fenamiphos sulfone & 1 & 61645 & 147 & 143 & 127 & 142 & 116 & 142 \\
\hline Fenamiphos sulfoxide & 1 & 61646 & 46 & 67 & 0 & 43 & 17 & 43 \\
\hline Fipronil & 1 & 62166 & 130 & 120 & 133 & 131 & 184 & 131 \\
\hline Fipronil sulfide & 1 & 62167 & 136 & 124 & 123 & 119 & 206 & 124 \\
\hline Fipronil sulfone & 1 & 62168 & 86 & 85 & 107 & 112 & 114 & 107 \\
\hline Fonofos & 1 & 04095 & 108 & 105 & 84 & 99 & 99 & 99 \\
\hline Hexazinone & 1 & 04025 & 87 & 95 & 69 & 95 & 103 & 95 \\
\hline Iprodione & 1 & 61593 & 127 & 124 & 104 & 111 & 136 & 124 \\
\hline Isofenphos & 1 & 61594 & 152 & 141 & 121 & 117 & 192 & 141 \\
\hline Malaoxon & 1 & 61652 & 55 & 104 & 112 & 135 & 153 & 112 \\
\hline Malathion & 1 & 39532 & 114 & 119 & 113 & 115 & 155 & 115 \\
\hline Metalaxyl & 1 & 61596 & 116 & 113 & 111 & 114 & 156 & 114 \\
\hline Methidathion & 1 & 61598 & 94 & 93 & 111 & 116 & 115 & 111 \\
\hline Methyl parathion & 1 & 82667 & 98 & 99 & 97 & 114 & 129 & 99 \\
\hline Metolachlor & 1 & 39415 & 129 & 118 & 110 & 105 & 143 & 118 \\
\hline Metribuzin & 1 & 82630 & 83 & 80 & 108 & 104 & 140 & 104 \\
\hline Myclobutanil & 1 & 61599 & 105 & 103 & 112 & 117 & 117 & 112 \\
\hline Paraoxon-methyl & 1 & 61664 & 27 & 73 & 67 & 112 & 116 & 73 \\
\hline Pendimethalin & 1 & 82683 & 146 & 143 & 109 & 108 & 142 & 142 \\
\hline Phorate & 1 & 82664 & 31 & 26 & 79 & 62 & 102 & 62 \\
\hline Phorate oxygen analog & 1 & 61666 & 60 & 75 & 112 & 120 & 146 & 112 \\
\hline Phosmet & 1 & 61601 & 42 & 47 & 95 & 93 & 72 & 72 \\
\hline Phosmet oxon & 1 & 61668 & 22 & 29 & 115 & 94 & 40 & 40 \\
\hline Prometon & 1 & 04037 & 102 & 94 & 104 & 99 & 125 & 102 \\
\hline Prometryn & 1 & 04036 & 114 & 107 & 117 & 110 & 146 & 114 \\
\hline Pronamide & 1 & 82676 & 113 & 106 & 102 & 99 & 133 & 106 \\
\hline Simazine & 1 & 04035 & 110 & 102 & 108 & 102 & 144 & 108 \\
\hline
\end{tabular}


Appendix 3. Percent recoveries of anthropogenic organic compounds for environmental matrix spike samples.-Continued

[USGS, U.S. Geological Survey; --, not available]

\begin{tabular}{|c|c|c|c|c|c|c|c|c|}
\hline \multirow[t]{2}{*}{ Analyte } & \multirow[t]{2}{*}{$\begin{array}{l}\text { Analytical } \\
\text { method }\end{array}$} & \multirow[t]{2}{*}{$\begin{array}{c}\text { USGS } \\
\text { parameter } \\
\text { code }\end{array}$} & \multirow{2}{*}{$\begin{array}{c}\text { Big Sioux } \\
\text { River (site } \\
\text { 433600096442400) } \\
8 / 3 / 2009\end{array}$} & \multirow{2}{*}{$\begin{array}{c}\text { Finished } \\
\text { water (site } \\
433419096434200 \text { ) }\end{array}$} & \multirow{2}{*}{$\begin{array}{c}\text { Ground- } \\
\text { water (site } \\
433421096434401) \\
2 / 17 / 2010\end{array}$} & \multirow{2}{*}{$\begin{array}{c}\begin{array}{c}\text { Finished } \\
\text { water (site } \\
\text { 433419096434200) }\end{array} \\
2 / 17 / 2010\end{array}$} & \multirow{2}{*}{$\begin{array}{c}\begin{array}{c}\text { Ground- } \\
\text { water (site } \\
433421096434401 \text { ) }\end{array} \\
7 / 29 / 2010\end{array}$} & \multirow[t]{2}{*}{ Median } \\
\hline & & & & & & & & \\
\hline Tebuthiuron & 1 & 82670 & 135 & 139 & 181 & 197 & 172 & 172 \\
\hline Terbufos & 1 & 82675 & 74 & 71 & 91 & 93 & 113 & 91 \\
\hline Terbufos oxygen analog sulfone & 1 & 61674 & 59 & 121 & 102 & 138 & 176 & 121 \\
\hline Terbuthylazine & 1 & 04022 & 114 & 106 & 112 & 106 & 121 & 112 \\
\hline Tribufos & 1 & 61610 & 101 & 99 & 78 & 87 & 83 & 87 \\
\hline Trifluralin & 1 & 82661 & 79 & 81 & 87 & 94 & 95 & 87 \\
\hline 1,7-Dimethylxanthine & 2 & 62030 & 63 & 38 & 76 & 42 & 62 & 62 \\
\hline Acetaminophen & 2 & 62000 & 44 & 20 & 60 & 25 & 50 & 44 \\
\hline Albuterol & 2 & 62020 & 65 & 26 & 76 & 32 & 58 & 58 \\
\hline Caffeine & 2 & 50305 & 86 & 71 & 116 & 87 & 72 & 86 \\
\hline Carbamazepine & 2 & 62793 & 51 & 62 & 62 & 59 & 44 & 59 \\
\hline Codeine & 2 & 62003 & 78 & 77 & 94 & 83 & 73 & 78 \\
\hline Cotinine & 2 & 62005 & 60 & 48 & 69 & 41 & 65 & 60 \\
\hline Dehydronifedipine & 2 & 62004 & 90 & 96 & 99 & 95 & 85 & 95 \\
\hline Diltiazem & 2 & 62008 & 45 & 66 & 70 & 78 & 34 & 66 \\
\hline Diphenhydramine & 2 & 62796 & 50 & 66 & 71 & 78 & 34 & 66 \\
\hline Sulfamethoxazole & 2 & 62021 & 14 & 25 & 41 & 35 & 26 & 26 \\
\hline Thiabendazole & 2 & 62801 & 55 & 66 & 62 & 75 & 21 & 62 \\
\hline Trimethoprim & 2 & 62023 & 61 & 68 & 84 & 83 & 50 & 68 \\
\hline Warfarin & 2 & 62024 & 62 & 84 & 89 & 77 & 72 & 77 \\
\hline 1-Methylnaphthalene & 3 & 81696 & 42 & 69 & 71 & 73 & 96 & 71 \\
\hline 1,4-Dichlorobenzene & 3 & 34571 & 37 & 65 & 65 & 68 & 91 & 65 \\
\hline 2-Methylnaphthalene & 3 & 30194 & 43 & 72 & 70 & 74 & 97 & 72 \\
\hline 2,6-Dimethylnaphthalene & 3 & 62805 & 41 & 73 & 67 & 73 & 94 & 73 \\
\hline 3-beta-Coprostanol & 3 & 62806 & 31 & 62 & 27 & 33 & 60 & 33 \\
\hline 3-Methyl-1H-indole & 3 & 62807 & 37 & 77 & 73 & 76 & 88 & 76 \\
\hline 3-tert-Butyl-4-hydroxyanisole & 3 & 61702 & 3 & 74 & 55 & 67 & 74 & 67 \\
\hline 3,4-Dichlorophenyl isocyanate & 3 & 63145 & 15 & 37 & 18 & 25 & 63 & 25 \\
\hline 4-Cumylphenol & 3 & 62808 & 62 & 94 & 67 & 81 & 114 & 81 \\
\hline
\end{tabular}




\begin{tabular}{|c|c|c|c|c|c|c|c|c|}
\hline \multirow[t]{2}{*}{ Analyte } & \multirow[t]{2}{*}{$\begin{array}{l}\text { Analytical } \\
\text { method }\end{array}$} & \multirow[t]{2}{*}{$\begin{array}{c}\text { USGS } \\
\text { parameter } \\
\text { code }\end{array}$} & \multirow{2}{*}{$\begin{array}{c}\text { Big Sioux } \\
\text { River (site } \\
433600096442400) \\
8 / 3 / 2009\end{array}$} & \multirow{2}{*}{$\begin{array}{c}\begin{array}{c}\text { Finished } \\
\text { water (site } \\
433419096434200)\end{array} \\
8 / 3 / 2009\end{array}$} & \multirow{2}{*}{$\begin{array}{c}\begin{array}{c}\text { Ground- } \\
\text { water (site } \\
433421096434401)\end{array} \\
2 / 17 / 2010\end{array}$} & \multirow{2}{*}{$\begin{array}{c}\text { Finished } \\
\text { water (site } \\
433419096434200)\end{array}$} & \multirow{2}{*}{$\begin{array}{c}\begin{array}{c}\text { Ground- } \\
\text { water (site } \\
\text { 433421096434401) }\end{array} \\
7 / 29 / 2010\end{array}$} & \multirow[t]{2}{*}{ Median } \\
\hline & & & & & & & & \\
\hline 4-n-Octylphenol & 3 & 62809 & 48 & 89 & 67 & 83 & 107 & 83 \\
\hline 4-Nonylphenol & 3 & 62829 & 48 & 76 & 66 & 76 & 116 & 76 \\
\hline 4-Nonylphenol diethoxylate & 3 & 61703 & 55 & 88 & 66 & 79 & 117 & 79 \\
\hline 4-Nonylphenol monoethoxylate & 3 & 61704 & 59 & 90 & 72 & 83 & 122 & 83 \\
\hline 4-Octylphenol diethoxylate & 3 & 62486 & 79 & 117 & 73 & 78 & 130 & 79 \\
\hline 4-Octylphenol monoethoxylate & 3 & 62485 & 80 & 112 & 74 & 86 & 118 & 86 \\
\hline 4-tert-Octylphenol & 3 & 62810 & 61 & 107 & 76 & 85 & 117 & 85 \\
\hline 5-Methyl-1H-benzotriazole & 3 & 61944 & 35 & 59 & -- & -- & 96 & 59 \\
\hline Acetophenone & 3 & 62811 & 54 & 83 & 68 & 80 & 101 & 80 \\
\hline Acetyl-hexamethyl-tetrahydro-naphthalene & 3 & 62812 & 43 & 83 & 59 & 69 & 110 & 69 \\
\hline Anthracene & 3 & 34220 & 42 & 81 & 69 & 80 & 98 & 80 \\
\hline Anthraquinone & 3 & 62813 & 78 & 94 & 75 & 82 & 121 & 82 \\
\hline Atrazine & 3 & 39630 & 65 & 88 & 69 & 85 & -- & 77 \\
\hline BDE congener 47 & 3 & 63147 & 39 & 90 & 43 & 56 & 96 & 56 \\
\hline Benzo[a]pyrene & 3 & 34247 & 24 & 50 & 44 & 56 & 81 & 50 \\
\hline Benzophenone & 3 & 62814 & 63 & 97 & 80 & 89 & 113 & 89 \\
\hline beta-Sitosterol & 3 & 62815 & 18 & 52 & 27 & 33 & 64 & 33 \\
\hline beta-Stigmastanol & 3 & 61948 & 32 & 50 & 29 & 37 & 65 & 37 \\
\hline Bis(2-ethylhexyl) phthalate & 3 & 39100 & 25 & 73 & 1 & 46 & 0 & 25 \\
\hline Bisphenol A & 3 & 62816 & 60 & 92 & 68 & 89 & 157 & 89 \\
\hline Bromacil & 3 & 30234 & 68 & 102 & 65 & 82 & 122 & 82 \\
\hline Bromoform & 3 & 32104 & 41 & 67 & 69 & 81 & 94 & 69 \\
\hline Caffeine & 3 & 81436 & 45 & 71 & 51 & 69 & 103 & 69 \\
\hline Camphor & 3 & 62817 & 46 & 73 & 71 & 75 & 96 & 73 \\
\hline Carbaryl & 3 & 39750 & 98 & 126 & 113 & 139 & 194 & 126 \\
\hline Carbazole & 3 & 77571 & 50 & 76 & 70 & 83 & 111 & 76 \\
\hline Chlorpyrifos & 3 & 38932 & 36 & 67 & 58 & 68 & 95 & 67 \\
\hline Cholesterol & 3 & 62818 & 4 & 62 & 28 & 33 & 65 & 33 \\
\hline Cotinine & 3 & 61945 & 35 & 54 & 23 & 36 & 78 & 36 \\
\hline
\end{tabular}


Appendix 3. Percent recoveries of anthropogenic organic compounds for environmental matrix spike samples.-Continued

[USGS, U.S. Geological Survey; --, not available]

\begin{tabular}{|c|c|c|c|c|c|c|c|c|}
\hline \multirow[t]{2}{*}{ Analyte } & \multirow[t]{2}{*}{$\begin{array}{l}\text { Analytical } \\
\text { method }\end{array}$} & \multirow{2}{*}{$\begin{array}{c}\text { USGS } \\
\text { parameter } \\
\text { code }\end{array}$} & $\begin{array}{c}\text { Big Sioux } \\
\text { River (site } \\
\text { 433600096442400) }\end{array}$ & $\begin{array}{c}\text { Finished } \\
\text { water (site } \\
433419096434200)\end{array}$ & $\begin{array}{c}\text { Ground- } \\
\text { water (site } \\
\text { 433421096434401) }\end{array}$ & $\begin{array}{c}\text { Finished } \\
\text { water (site } \\
\text { 433419096434200) }\end{array}$ & $\begin{array}{c}\text { Ground- } \\
\text { water (site } \\
\text { 433421096434401) }\end{array}$ & \multirow[t]{2}{*}{ Median } \\
\hline & & & $8 / 3 / 2009$ & $8 / 3 / 2009$ & 2/17/2010 & 2/17/2010 & 7/29/2010 & \\
\hline Diazinon & 3 & 39570 & 45 & 74 & 57 & 66 & 111 & 66 \\
\hline Dichlorvos & 3 & 30218 & 57 & 86 & 74 & 81 & 127 & 81 \\
\hline Diethyl phthalate & 3 & 34336 & 65 & 89 & 58 & 86 & 120 & 86 \\
\hline D-Limonene & 3 & 62819 & 28 & 50 & 40 & 42 & 74 & 42 \\
\hline Fluoranthene & 3 & 34376 & 40 & 79 & 69 & 79 & 105 & 79 \\
\hline Hexahydrohexamethyl cyclopentabenzopyran & 3 & 62823 & 44 & 76 & 61 & 77 & 103 & 76 \\
\hline Indole & 3 & 62824 & 34 & 70 & 61 & 69 & 93 & 69 \\
\hline Isoborneol & 3 & 62825 & 43 & 71 & 70 & 77 & 91 & 71 \\
\hline Isophorone & 3 & 34408 & 48 & 73 & 73 & 74 & 98 & 73 \\
\hline Isopropylbenzene & 3 & 77223 & 30 & 54 & 46 & 56 & 81 & 54 \\
\hline Isoquinoline & 3 & 62826 & 49 & 81 & 43 & 58 & -- & 54 \\
\hline Menthol & 3 & 62827 & 41 & 71 & 70 & 78 & 87 & 71 \\
\hline Metalaxyl & 3 & 04254 & 61 & 89 & 66 & 85 & 119 & 85 \\
\hline Methyl salicylate & 3 & 62828 & 53 & 84 & 74 & 78 & 105 & 78 \\
\hline Metolachlor & 3 & 82612 & 53 & 88 & 69 & 85 & 113 & 85 \\
\hline Naphthalene & 3 & 34696 & 47 & 77 & 71 & 76 & 95 & 76 \\
\hline N,N-Diethyl-meta-toluamide (DEET) & 3 & 61947 & 64 & 84 & 77 & 91 & 124 & 84 \\
\hline$p$-Cresol & 3 & 77146 & 41 & 80 & 66 & 76 & 100 & 76 \\
\hline Pentachlorophenol & 3 & 39032 & 2 & 75 & 83 & 95 & 134 & 83 \\
\hline Phenanthrene & 3 & 34461 & 42 & 78 & 68 & 81 & 97 & 78 \\
\hline Phenol & 3 & 34694 & -46 & 71 & 41 & 60 & 82 & 60 \\
\hline Prometon & 3 & 39056 & 59 & 88 & 63 & 77 & 106 & 77 \\
\hline Pyrene & 3 & 34469 & 37 & 79 & 66 & 79 & 106 & 79 \\
\hline Tetrachloroethylene & 3 & 34475 & 18 & 40 & 34 & 40 & 64 & 40 \\
\hline Tributyl phosphate & 3 & 62832 & 67 & 99 & 78 & 94 & 127 & 94 \\
\hline Triclosan & 3 & 61708 & 53 & 76 & 62 & 73 & 114 & 73 \\
\hline Triethyl citrate & 3 & 62833 & 60 & 92 & 71 & 87 & 121 & 87 \\
\hline Triphenyl phosphate & 3 & 62834 & 51 & 79 & 61 & 70 & 108 & 70 \\
\hline Tris(2-butoxyethyl) phosphate & 3 & 62830 & 55 & 78 & 63 & 78 & 110 & 78 \\
\hline
\end{tabular}




\begin{tabular}{|c|c|c|c|c|c|c|c|c|}
\hline \multirow[t]{2}{*}{ Analyte } & \multirow[t]{2}{*}{$\begin{array}{l}\text { Analytical } \\
\text { method }\end{array}$} & \multirow{2}{*}{$\begin{array}{c}\text { USGS } \\
\text { parameter } \\
\text { code }\end{array}$} & $\begin{array}{c}\text { Big Sioux } \\
\text { River (site } \\
\text { 433600096442400) }\end{array}$ & $\begin{array}{c}\text { Finished } \\
\text { water (site } \\
\text { 433419096434200) }\end{array}$ & $\begin{array}{c}\text { Ground- } \\
\text { water (site } \\
\text { 433421096434401) }\end{array}$ & $\begin{array}{c}\text { Finished } \\
\text { water (site } \\
\text { 433419096434200) }\end{array}$ & $\begin{array}{c}\text { Ground- } \\
\text { water (site } \\
\text { 433421096434401) }\end{array}$ & \multirow[t]{2}{*}{ Median } \\
\hline & & & $8 / 3 / 2009$ & $8 / 3 / 2009$ & 2/17/2010 & $2 / 17 / 2010$ & $7 / 29 / 2010$ & \\
\hline Tris(2-chloroethyl) phosphate & 3 & 62831 & 58 & 84 & 65 & 79 & 120 & 79 \\
\hline Tris(dichloroisopropyl) phosphate & 3 & 61707 & 52 & 76 & 56 & 69 & 117 & 69 \\
\hline 4-Epioxytetracycline & 4 & 63729 & 0 & 0 & 111 & 133 & 102 & 102 \\
\hline 4-Epitetracycline hydrochloride & 4 & 63727 & 7 & 6 & 90 & 108 & 94 & 90 \\
\hline Anhydroerthromycin & 4 & 63674 & 98 & 103 & 116 & 118 & 129 & 116 \\
\hline Azithromycin & 4 & 62792 & 52 & 89 & 130 & 197 & 105 & 105 \\
\hline Carbamazepine & 4 & 62793 & 106 & 112 & 82 & 101 & 91 & 101 \\
\hline Chloramphenicol & 4 & 65194 & 0 & 0 & 106 & 127 & 122 & 106 \\
\hline Chlortetracycline & 4 & 61744 & 282 & 317 & 96 & 97 & 112 & 112 \\
\hline Ciprofloxacin & 4 & 62898 & 101 & 115 & 142 & 164 & 127 & 127 \\
\hline Doxycycline & 4 & 62694 & 102 & 110 & 64 & 76 & 82 & 82 \\
\hline Enrofloxacin & 4 & 66495 & 96 & 97 & 61 & 77 & 66 & 77 \\
\hline Erythromycin & 4 & 62797 & 44 & 48 & 140 & 140 & 156 & 140 \\
\hline Ibuprofen & 4 & 62014 & 90 & 94 & 93 & 134 & 116 & 94 \\
\hline Lincomycin & 4 & 62894 & 106 & 93 & 131 & 191 & 243 & 131 \\
\hline Lomefloxacin & 4 & 62900 & 95 & 97 & 60 & 74 & 69 & 74 \\
\hline Norfloxacin & 4 & 62757 & 92 & 91 & 55 & 71 & 69 & 71 \\
\hline Ofloxacin & 4 & 62899 & 103 & 101 & 54 & 68 & 59 & 68 \\
\hline Ormetoprim & 4 & 62962 & 106 & 111 & 105 & 118 & 116 & 111 \\
\hline Oxytetracycline & 4 & 61759 & 145 & 157 & 128 & 151 & 129 & 145 \\
\hline Roxithromycin & 4 & 62895 & 87 & 88 & 116 & 137 & 130 & 116 \\
\hline Sarafloxacin & 4 & 62771 & 78 & 74 & 50 & 65 & 59 & 65 \\
\hline Sulfachlorpyridazine & 4 & 62774 & 97 & 109 & 85 & 103 & 88 & 97 \\
\hline Sulfadiazine & 4 & 62963 & 141 & 112 & 66 & 93 & 68 & 93 \\
\hline Sulfadimethoxine & 4 & 62776 & 182 & 157 & 67 & 81 & 79 & 81 \\
\hline Sulfamethazine & 4 & 61762 & 144 & 111 & 115 & 138 & 124 & 124 \\
\hline Sulfamethoxazole & 4 & 62775 & 123 & 100 & 105 & 129 & 117 & 117 \\
\hline Sulfathiazole & 4 & 62778 & 120 & 110 & 72 & 94 & 64 & 94 \\
\hline Tetracycline & 4 & 62781 & 117 & 127 & 97 & 124 & 101 & 117 \\
\hline
\end{tabular}


Appendix 3. Percent recoveries of anthropogenic organic compounds for environmental matrix spike samples.-Continued

[USGS, U.S. Geological Survey; --, not available]

\begin{tabular}{|c|c|c|c|c|c|c|c|c|}
\hline \multirow[t]{2}{*}{ Analyte } & \multirow[t]{2}{*}{$\begin{array}{c}\text { Analytical } \\
\text { method }\end{array}$} & \multirow{2}{*}{$\begin{array}{l}\text { USGS } \\
\text { parameter } \\
\text { code }\end{array}$} & $\begin{array}{c}\text { Big Sioux } \\
\text { River (site } \\
\text { 433600096442400) } \\
\end{array}$ & $\begin{array}{c}\text { Finished } \\
\text { water (site } \\
\text { 433419096434200) }\end{array}$ & $\begin{array}{c}\text { Ground- } \\
\text { water (site } \\
\text { 433421096434401) }\end{array}$ & $\begin{array}{c}\text { Finished } \\
\text { water (site } \\
\text { 433419096434200) }\end{array}$ & $\begin{array}{c}\text { Ground- } \\
\text { water (site } \\
\text { 433421096434401) }\end{array}$ & \multirow[t]{2}{*}{ Median } \\
\hline & & & $8 / 3 / 2009$ & $8 / 3 / 2009$ & 2/17/2010 & 2/17/2010 & $7 / 29 / 2010$ & \\
\hline Trimethoprim & 4 & 62023 & 90 & 109 & 105 & 129 & 117 & 109 \\
\hline Tylosin & 4 & 62896 & 104 & 97 & 107 & 120 & 94 & 104 \\
\hline Virginiamycin & 4 & 62897 & 51 & 213 & 126 & 168 & 190 & 168 \\
\hline 4-Androstene-3,17-dione & 5 & 64533 & 81 & 76 & 102 & 94 & 92 & 92 \\
\hline 11-Ketotestosterone & 5 & 64527 & 89 & 96 & 99 & 91 & 82 & 91 \\
\hline 17-alpha-Estradiol & 5 & 64528 & 101 & 97 & 101 & 110 & 86 & 101 \\
\hline 17-alpha-Ethynylestradiol & 5 & 64529 & 73 & 76 & 98 & 100 & 99 & 98 \\
\hline 17-beta-Estradiol & 5 & 64530 & 91 & 89 & 100 & 108 & 99 & 99 \\
\hline Bisphenol A & 5 & 67305 & 72 & 73 & 80 & 76 & 88 & 76 \\
\hline Cholesterol & 5 & 64534 & 98 & 77 & 65 & 77 & 95 & 77 \\
\hline cis-Androsterone & 5 & 64535 & 134 & 111 & 103 & 101 & 126 & 111 \\
\hline Dihydrotestosterone & 5 & 64544 & 87 & 102 & 95 & 95 & 134 & 95 \\
\hline Epitestosterone & 5 & 64537 & 105 & 91 & 103 & 100 & 106 & 103 \\
\hline Equilenin & 5 & 64538 & 44 & 91 & 49 & 95 & 68 & 68 \\
\hline Equilin & 5 & 64539 & 139 & 134 & 73 & 97 & 76 & 97 \\
\hline Estriol & 5 & 64540 & 89 & 92 & 99 & 102 & 63 & 92 \\
\hline Estrone & 5 & 64541 & 96 & 87 & 116 & 109 & 104 & 104 \\
\hline Mestranol & 5 & 64542 & 91 & 85 & 101 & 92 & 100 & 92 \\
\hline Norethindrone & 5 & 64531 & 78 & 72 & 106 & 93 & 92 & 92 \\
\hline Progesterone & 5 & 64543 & 152 & 76 & 93 & 92 & 86 & 92 \\
\hline Testosterone & 5 & 64545 & 82 & 78 & 102 & 96 & 131 & 96 \\
\hline trans-Diethylstilbestrol & 5 & 64536 & 60 & 76 & 8 & 98 & 89 & 76 \\
\hline
\end{tabular}


Appendix 4. Physical Properties and Concentrations of Anthropogenic Organic Compounds in Source and Finished Water

The Excel file can be accessed at http://pubs.usgs.gov/sir/2012/5098/downloads/appendix-4.xlsx.

Publishing support provided by:

Rolla Publishing Service Center

For more information concerning this publication, contact:

Director, USGS South Dakota Water Science Center

1608 Mt. View Road

Rapid City, SD 57702

(605) 394-3200

Or visit the South Dakota Water Science Center Web site at: http://sd.water.usgs.gov 
Back cover inset photographs. Clockwise from left: Pump and sampling tap used at the surface-water intake station on the Big Sioux River. View of Big Sioux River north of Sioux Falls, showing the natural channel flowing from bottom left to right and diversion channel to the top left. Low-head dam on the Big Sioux River diversion channel north of Sioux Falls. 

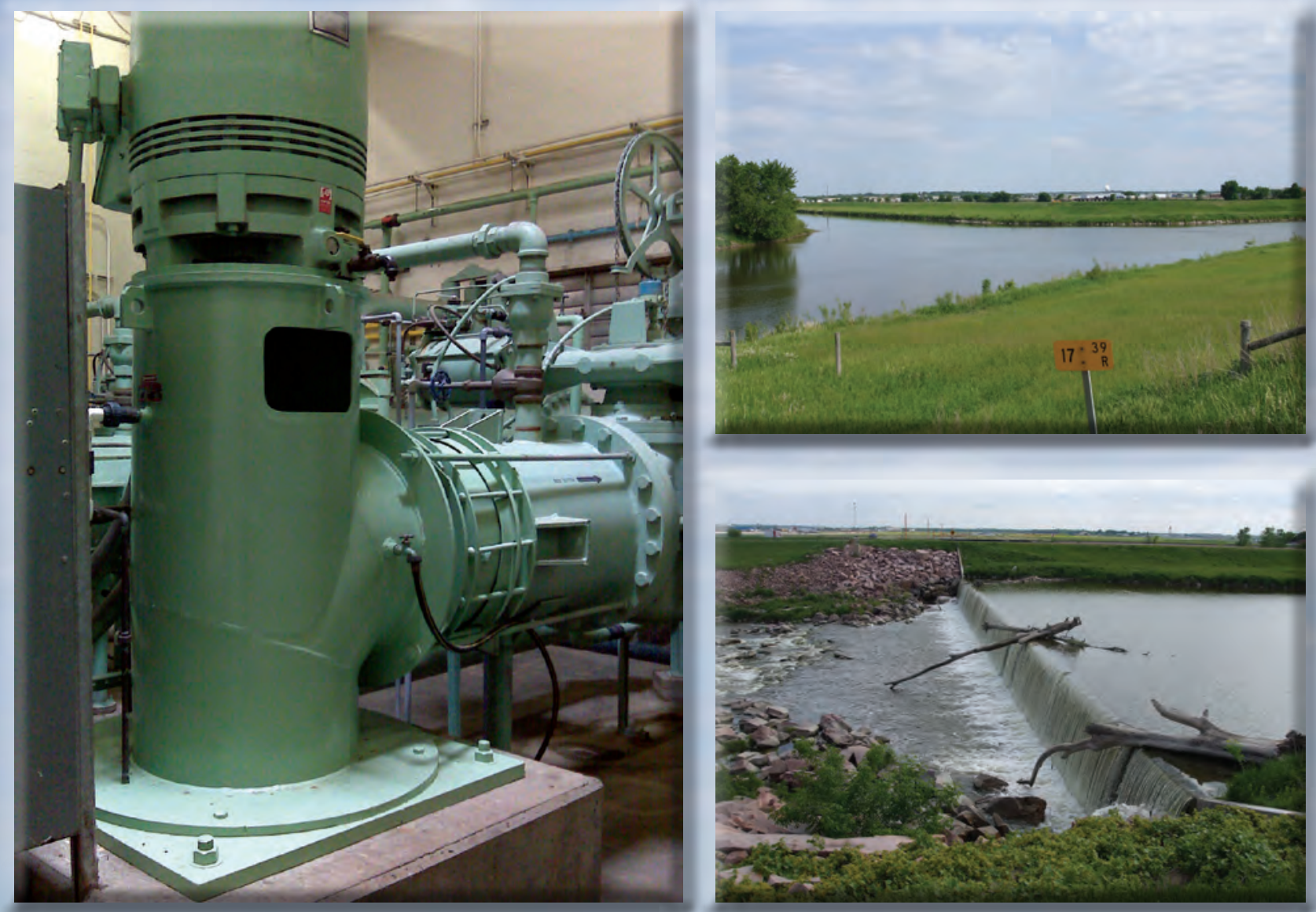